\title{
The significance of intermetallic compounds formed during interdiffusion in aluminum and magnesium dissimilar welds
}

DOI:

10.1016/j.matchar.2017.09.040

\section{Document Version}

Accepted author manuscript

Link to publication record in Manchester Research Explorer

Citation for published version (APA):

Wang, Y., \& Prangnell, P. (2017). The significance of intermetallic compounds formed during interdiffusion in aluminum and magnesium dissimilar welds. Materials Characterization, 134, 84-95.

https://doi.org/10.1016/j.matchar.2017.09.040

\section{Published in:}

Materials Characterization

\section{Citing this paper}

Please note that where the full-text provided on Manchester Research Explorer is the Author Accepted Manuscript or Proof version this may differ from the final Published version. If citing, it is advised that you check and use the publisher's definitive version.

\section{General rights}

Copyright and moral rights for the publications made accessible in the Research Explorer are retained by the authors and/or other copyright owners and it is a condition of accessing publications that users recognise and abide by the legal requirements associated with these rights.

\section{Takedown policy}

If you believe that this document breaches copyright please refer to the University of Manchester's Takedown Procedures [http://man.ac.uk/04Y6Bo] or contact uml.scholarlycommunications@manchester.ac.uk providing relevant details, so we can investigate your claim.

\section{OPEN ACCESS}




\title{
The significance of intermetallic compounds formed during interdiffusion in aluminum and magnesium dissimilar welds
}

\begin{abstract}
Diffusion couples between Al-AA6111 and Mg-AZ31 have been used to perform a comprehensive review of the IMC phases that develop in this system, including; their growth kinetics, texture, residual stresses, and mechanical properties. The new observations made have been compared to data in the literature with the aim of providing an in-depth understanding of the detrimental effects of interfacial reaction in aluminum - magnesium dissimilar welding. Three Al-Mg binary IMC phases were identified, $\gamma-\mathrm{Al}_{12} \mathrm{Mg}_{17}$ and $\beta-\mathrm{Al}_{3} \mathrm{Mg}_{2}$, as well as $\varepsilon-\mathrm{Al}_{30} \mathrm{Mg}_{23}$, which has not been previously reported in inter-diffusion studies. The $\beta$ phase had the highest growth rate and became the dominant constituent of the IMC layer at longer reaction times. The $\varepsilon$-phase only appeared after extended heat treatment, via transformation at the $\mathrm{Al}_{12} \mathrm{Mg}_{17} / \mathrm{Al}_{3} \mathrm{Mg}_{2}$ interface. Intrinsic diffusion coefficients of $\mathrm{Al}$ and $\mathrm{Mg}$, calculated in the $\mathrm{Al}_{3} \mathrm{Mg}_{2}$ phase, confirmed that $\mathrm{Al}$ is the faster diffusing species (by an order of magnitude) during IMC growth. Indentation techniques showed that all the IMC phases had extremely low toughness $\left(<0.1 \mathrm{MPam}^{1 / 2}\right)$. FIB-assisted ring core milling revealed that both the $\beta-\mathrm{Al}_{3} \mathrm{Mg}_{2}$ and $\gamma-\mathrm{Al}_{12} \mathrm{Mg}_{17}$ phases contained large residual stresses. Their in-situ fracture toughness was consequently found to be asymmetric with lower values parallel to the joint interface. Greater tensile residual stress was measured in the $\beta-\mathrm{Al}_{3} \mathrm{Mg}_{2}$ phase, which, combined with a lower toughness and more rapid growth kinetics, explains why it is generally the 'weak link' in $\mathrm{Al}-\mathrm{Mg}$ dissimilar joints.
\end{abstract}




\subsection{Introduction}

Aluminum ( $\mathrm{Al})$ and Magnesium $(\mathrm{Mg})$ multi-material structures have potential to reduce weight in the automotive industry [1]. However, currently there is no satisfactory method for welding Al to $\mathrm{Mg}$ because the joints are adversely affected by the rapid formation of brittle intermetallic compounds (IMCs) [2-5]. Although most research to date has focused on solid-state welding (e.g. friction stir, ultrasonic, etc.) to try to reduce IMC formation, the reaction rate is high and this can result in a thick IMC layer being produced at the joint interface even with very short thermal cycles $[2,3,6]$. As interfacial reaction is one of the main factors preventing acceptable weld performance, it is desirable to obtain a deeper insight into IMC formation in the $\mathrm{Al}-\mathrm{Mg}$ system during inter-diffusion. In particular, a more comprehensive fundamental understanding of the formation, growth kinetics, and mechanical properties of the IMC phases is essential before exploring strategies for improving dissimilar welding technologies.

Unfortunately, the thermodynamic assessment of the $\mathrm{Al}-\mathrm{Mg}$ system required to support a full understanding of IMC reaction during inter-diffusion is still incomplete. Although the two most frequently quoted versions of the Al-Mg phase diagram, proposed by Murray [7] and Schurmann et al.[8] provide a consistent description of the two main intermetallic phases, $\gamma-\mathrm{Al}_{12} \mathrm{Mg}_{17}$ and $\beta-\mathrm{Al}_{3} \mathrm{Mg}_{2}$, there is disagreement over the central part of the diagram in the composition range 40 60 at. $\% \mathrm{Mg}$. This lack of consensus centers on: i) the description of the $\varepsilon^{-} \mathrm{Al}_{30} \mathrm{Mg}_{23}$ phase (designated R phase by Murray [7]); and ii) whether a $\zeta$ phase exists. To attempt to clarify these phase relationships, Su et al. [9] have conducted long-term heat treatment studies on alloys cast within the controversial composition range and proposed that the $\varepsilon$ phase forms via a peritectoid reaction $(\beta+\gamma \rightarrow \varepsilon)$ at $410{ }^{\circ} \mathrm{C}$. They also reported a new phase, $\lambda$, at temperatures above $435{ }^{\circ} \mathrm{C}$, but the $\zeta$ phase was not detected. Based on their experimental observations, a third version of the phase diagram has been proposed (Fig. 1) [9]. Although this research has advanced knowledge of the Al-Mg equilibrium system, a general consensus and, in particular, a full description of the $\varepsilon$ phase is still absent in the literature.

In addition to the thermodynamic evaluation of the Al-Mg system, static inter-diffusion experiments have been conducted on $\mathrm{Al}-\mathrm{Mg}$ couples by several researchers that are highly relevant to solid state welding [10-20]. In this research, $\gamma-\mathrm{Al}_{12} \mathrm{Mg}_{17}$ and $\beta-\mathrm{Al}_{3} \mathrm{Mg}_{2}$ are the only two phases reported, and their growth rate has been found to follow the standard one-dimensional parabolic law with good agreement between the kinetic parameters by different groups (e.g. [10-13]). This suggests the growth rate is largely controlled by lattice diffusion and there is a low sensitivity to alloy composition [21]. To date, Dietrich et al. [20] have conducted one of the most thorough 
investigations of the $\gamma$ and $\beta$ intermetallic bi-layer formed at the Al-Mg interdiffusion interface, in terms of its microstructure and mechanical properties. By using electron backscattered diffraction (EBSD), they found that both intermetallic phases had a columnar grain structure, and that the $\gamma$ phase showed a weak <111> fiber texture. Kinetic data obtained for the individual $\gamma$ and $\beta$ phases [10] has also been used to model the growth rate of the $\gamma$ - $\beta$ IMC bi-layers with reasonable success [21]. Wang et al. [21] have combined Kidson's method with grain growth kinetics to account for the grain size effect on the interdiffusion behavior of the $\mathrm{Al}_{12} \mathrm{Mg}_{17}$ and $\mathrm{Al}_{3} \mathrm{Mg}_{2}$ phases formed in an $\mathrm{Al}-$ $\mathrm{Mg}$ reactive diffusion couple. Their modeling approach suggests that at temperatures below $400{ }^{\circ} \mathrm{C}$ the controlling mechanism for the $\mathrm{Al}_{12} \mathrm{Mg}_{17}$ phase was grain boundary diffusion, whereas for the

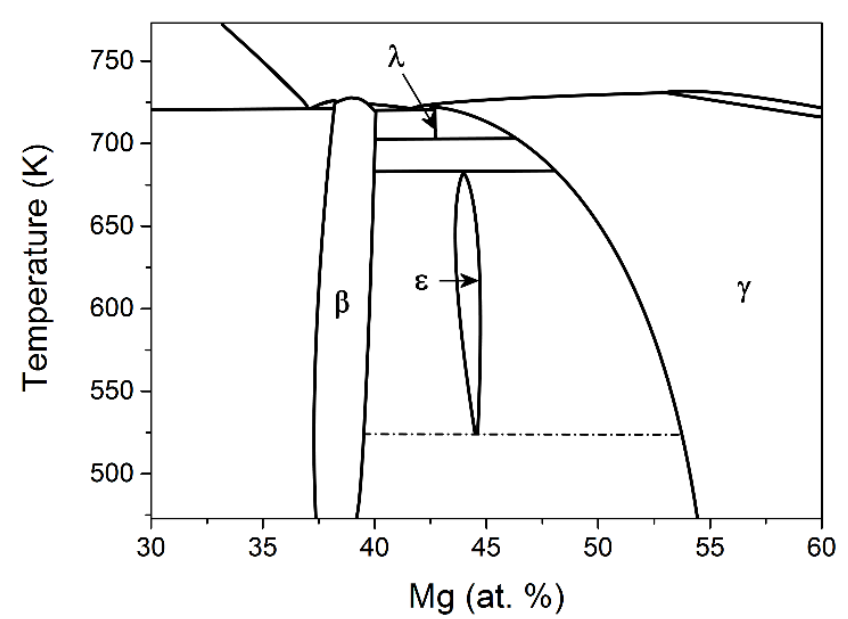

$\mathrm{Al}_{3} \mathrm{Mg}_{2}$ phase lattice diffusion was dominant.

Fig. 1 The revised middle section of Al-Mg phase diagram proposed by Su et al. [9].

Finally, the crystal structures of the main phases in the Al-Mg system (e.g. $\gamma, \beta$ ) have long been recognized to be unusually complex, which contributes to their high growth rate owing to the availability of unoccupied sites for diffusion [22-25].

Although there is now a good understanding of the growth behavior of the $\gamma$ and $\beta$ phases (e.g. [2, 12, 20, 26), in the context of Al-Mg dissimilar welding there still remains some important knowledge gaps. For example, while the $\varepsilon-\mathrm{Al}_{30} \mathrm{Mg}_{23}$ phase has been reported in the literature, it has not so far been observed in long-term diffusion couples, or welded joints, and its behavior largely remains unknown. In addition, there is limited data on the mechanical properties of the intermetallic phases, such as their fracture toughness, and residual stresses, which are important for determining weld performance. The current study therefore aims to provide a more comprehensive view of the 
$\mathrm{Al}-\mathrm{Mg}$ intermetallic reaction seen in $\mathrm{Al}-\mathrm{Mg}$ dissimilar joints, in terms of the nature of the phases developed and their inter-diffusion behavior, but also their mechanical properties and the residual stresses present in the IMC layer. The results obtained have been compared to data reviewed in the literature with the overall aim of providing a more reliable basis for understanding Al-Mg IMC reactions during dissimilar metal welding. It should be noted that high strain rate deformation is clearly an important aspect of many solid state welding techniques like friction stir welding processes and this will clearly alter the IMC reaction behavior by accelerating diffusion and breaking up IMC layers as they form. However, an improved basic understanding of the growth behavior, kinetics, and properties of the IMC phases is still important to underpin the development of dissimilar joining technologies.

\subsection{Experimental}

\subsection{Diffusion Bonding Experiments}

Two typical automotive aluminum and magnesium alloys (AA6111 and AZ31) were employed in this investigation (Table 1), used in a sheet form with a nominal thicknesses of $1 \mathrm{~mm}$. Inter-diffusion samples were prepared by cutting the sheets into $30 \mathrm{~mm} \times 30 \mathrm{~mm}$ squares and grinding off any oxide with 320-grit SiC paper, followed by rinsing with ethanol. To obtain intimate surface contact, the sheets were lightly welded together using a $2 \mathrm{~kW}$ Sonobond ultrasonic welder (USW) with a very short weld time of 0.2 seconds (full details are provided in $[2,26]$ ). The interface temperature reached for this short welding time was approximately $300{ }^{\circ} \mathrm{C}[2]$. The dissimilar joints were then heat-treated isothermally in a furnace under an argon inert atmosphere at a range of temperatures below the eutectic point of $437{ }^{\circ} \mathrm{C}$ for up to 72 hours. For comparison purposes, samples were also made with a pure Al (99.99\%) sheet and combined with the AZ31 magnesium alloy under identical conditions.

Table 1 Nominal compositions of the AA6111 and AZ31 alloys investigated (wt. \%).

\begin{tabular}{cccccccccc}
\hline & $\mathrm{Al}$ & $\mathrm{Si}$ & $\mathrm{Zn}$ & $\mathrm{Fe}$ & $\mathrm{Cu}$ & $\mathrm{Mn}$ & $\mathrm{Mg}$ \\
\cline { 1 - 3 } & AA6111 & Balance & $0.6-1.1$ & $<0.15$ & & $<0.4$ & $0.5-0.9$ & $0.1-0.45$ & $0.5-1$ \\
$\mathrm{AZ31}$ & $2.5-3.5$ & $<0.1$ & $0.7-1.3$ & - & - & $0.2-0.6$ & Balance \\
\hline
\end{tabular}

\subsection{Microstructural and Mechanical Characterization}

For all microstructural investigations, the $\mathrm{Al}-\mathrm{Mg}$ joints were sectioned parallel to the USW vibration direction using a thin diamond cutting wheel, to expose the ND (normal direction) - TD 
(transverse direction) plane. The cross sections were then ground and polished with diamond paste and an oil-based oxide particle suspension, to prevent corrosion of the magnesium and IMC phases. For EBSD analysis, a final step of broad ion beam milling was used with a Gatan Illion II System to obtain a strain-free surface. BSE and EBSD analysis were carried out on an FEI Magellan HR FEG-SEM equipped with EBSD and EDX detectors. TEM samples were prepared by focused ion beam (FIB) milling using an FEI Quanta 3D FIB and studied in an FEI Tecnai G2 20 TEM equipped with an EDX detector.

The in-situ mechanical properties of the IMCs in the reaction layer were evaluated using both micro- and nano-indentation techniques. For the micro-hardness tests, several indents were made using a standard Vickers pyramid indenter with a small applied load of $0.05 \mathrm{~kg}$ and averaged for each intermetallic phase. The hardness of the base materials were also obtained under identical conditions. The fracture toughness of the IMC phases was estimated from the hardness tests using the indent crack extension method [27] (discussed further below). Nano-indentation tests were also carried out using a standard 3-sided pyramidal (Berkovich) indentor. The results were averaged across the intermetallic layers from a matrix of $8 \times 3$ indents with a $5 \mu \mathrm{m}$ spacing. The unloading curves were used to extract the elastic modulus of each IMC layer.

\subsection{Residual Strain Measurements}

Residual strains within the IMC layer were measured using the FIB-assisted ring core milling technique developed by Sebastian et al. [28]. This involved first depositing a $4.5 \mu \mathrm{m}$ diameter circular protective platinum layer (with a thickness of $100 \mathrm{~nm}$ ) on the intermetallic phase of interest, in sectioned and metallographically prepared samples that had been heat-treated to produce thick reaction layers. A reference pattern composed of a matrix of small dots (with a diameter of $40 \mathrm{~nm}$ ) was milled into the platinum coating (see Fig. 2). To avoid re-disposition on the reference pattern, as well as to protect the edge of the coating during milling, a $300 \mathrm{~nm}$ thick platinum ring was deposited around the circumference of the coated area. A high-resolution reference image was then taken of the pattern. To progressively relax any residual strains, a ring was subsequently progressively milled into the surface with an inner and outer diameter of $4.5 \mu \mathrm{m}$ and $6.5 \mu \mathrm{m}$, to remove the material surrounding the platinum coating. The depth of each milling step was set at a nominal value of $0.05 \mu \mathrm{m}$, and a total of 10 repetitions was performed. After completion of each milling step an image of the reference pattern was re-acquired. The residual strains in both the interface plane and normal directions were then determined as a function of depth by measuring the displacement of the reference patterns using digital image correlation (DIC). 
DIC was performed with a Matlab®-based code developed at the Johns Hopkins University and the Karlsruhe Institute of Technology. The marker subset used was $12 \times 12$ pixels $^{2}$ in size, while the distance between markers was of $4 \times 4$ pixels $^{2}$. Due to redeposition on milling, the markers at the edge of the pillar exhibited poor resolution, and were excluded from strain calculations, leaving a final set of about 4000 markers for calculating the displacements with respect to the reference image. This data was then used to estimate the residual stresses in each IMC phase by using a plane stress approximation.

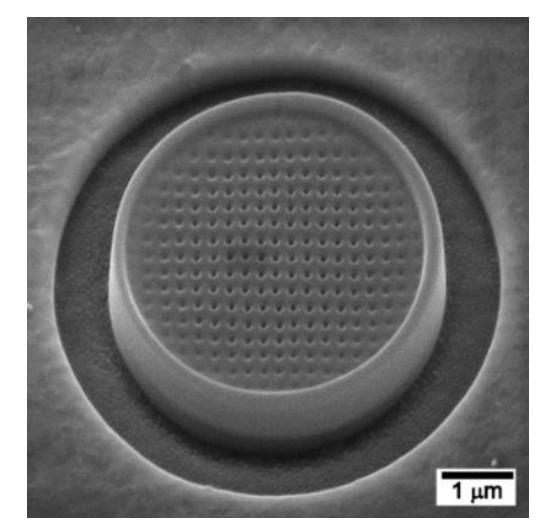

Fig. 2 Example of the cumulative ring-core milling procedure taken at an intermediate milling step.

\subsection{Results and Discussion}

\subsection{The Interface Microstructure Prior to Heat Treatment}

To evaluate the influence of the initial ultrasonic welding step on the starting condition of the pre-bonded $\mathrm{Al}$ (AA 6111) and Mg (AZ31) samples, their interfacial microstructure was first studied prior to heat treatment. From Fig. 3 it can be seen that following USW [26] a void-free interface was obtained between the parent materials and the intimate contact achieved provided an ideal starting condition for studying IMC growth during subsequent heat treatment. However, a thin $0-2$ $\mu \mathrm{m}$ thick intermetallic layer was already found to be present in the pre-welded samples. This layer was already continuous across the weld center where the temperature would have been highest. The IMC layer was indexed by EBSD as $\gamma-\mathrm{Al}_{12} \mathrm{Mg}_{17}$, which is also the phase normally first observed during static annealing experiments [20]. A much thinner second layer was also seen on the Al side of the joint, that could not be indexed, and this is probably the first evidence of the formation of the $\beta-\mathrm{Al}_{3} \mathrm{Mg}_{2}$ phase (see Fig. 4); i.e. the pre- welding step had no effect on the expected sequence of IMC formation [14-18, 20]. 

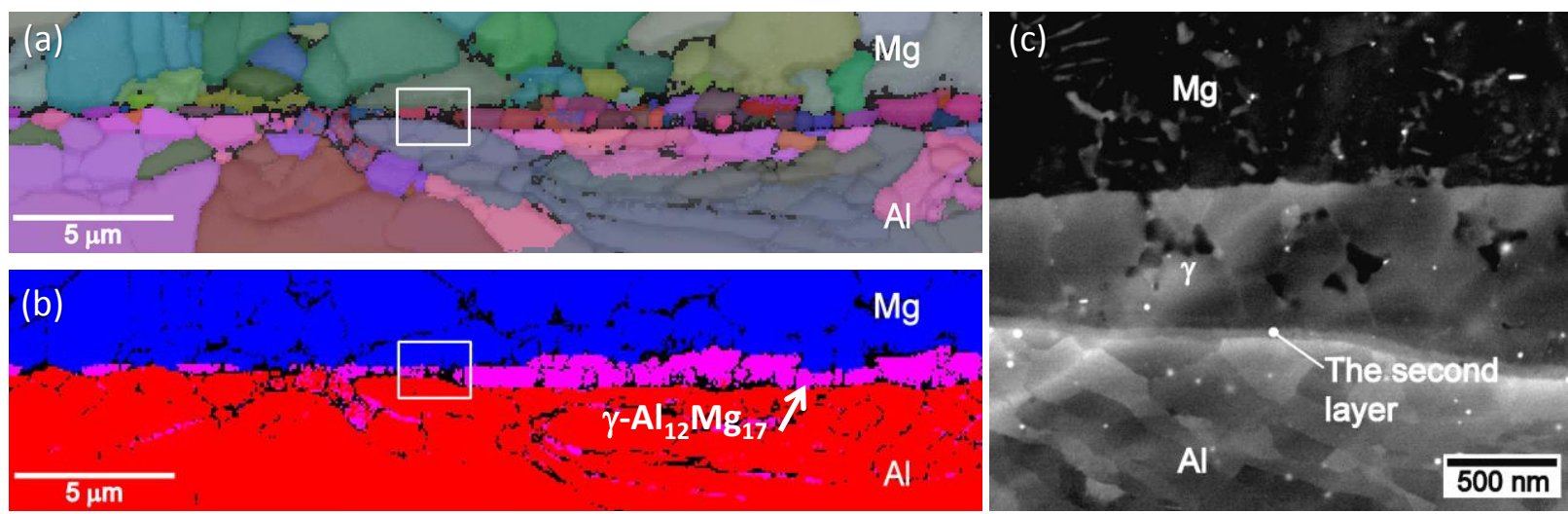

Fig. 3 The interfacial microstructure of the USW Al(AA 6111) - $\mathrm{Mg}(\mathrm{AZ31})$ samples prior to heat treatment; (a) EBSD Euler angle map, (b) EBSD phase map and (c) SEM image of the interface, showing a single thin reaction layer.

\subsection{Microstructure Development of the Interface Layer}

\section{Short Reaction Times}

After short heat treatment times the intermetallic reaction layer became continuous across the weld area, implying that the any local homogeneity inherited from USW was quickly eliminated (Fig. 4). In Fig. 4 after 5 minutes at $400{ }^{\circ} \mathrm{C}$, EBSD phase mapping revealed that at this stage the reaction layer was comprised of two continuous, distinct, IMC sublayers; $\gamma$ - $\mathrm{Al}_{12} \mathrm{Mg}_{17}$, which formed first, and $\beta-\mathrm{Al}_{3} \mathrm{Mg}_{2}$ (Fig. 4c) that formed between $\gamma-\mathrm{Al}_{12} \mathrm{Mg}_{17}$ and the $\mathrm{Al}$ substrate, as has been reported in several previous studies on $\mathrm{Al}-\mathrm{Mg}$ diffusion couples [14-18, 20]. However, in contrast to earlier published results that have typically focused on longer reaction times (e.g. [20]), the $\beta-\mathrm{Al}_{3} \mathrm{Mg}_{2}$ phase was found to be thinner than $\gamma-\mathrm{Al}_{12} \mathrm{Mg}_{17}$, indicating that the $\beta$ layer had only just started to grow.

In addition, EBSD orientation maps (Fig. 5b) revealed that the IMC sublayers had equiaxed grains, rather than the columnar structure normally reported for longer reaction times [20]. The two phases also had distinctively different grain sizes, with the crystallites in the $\beta-\mathrm{Al}_{3} \mathrm{Mg}_{2}$ layer being sub-micron $(0.5-1 \mu \mathrm{m})$, and those in the $\gamma$ - $\mathrm{Al}_{12} \mathrm{Mg}_{17}$ phase significantly larger $(1-3 \mu \mathrm{m})$. Moreover, from Fig. 4b, which shows an image near the edge of the welded area, it can be seen that the $\mathrm{Al}_{3} \mathrm{Mg}_{2}$ layer grew by migrating into the $\mathrm{Al}_{12} \mathrm{Mg}_{17}$ phase, as well as into the $\mathrm{Al}$ substrate, and that this process was hindered by coarse constituent precipitates originally present in the surface of the parent alloy that had been incorporated into the reaction layer (bright contrast). In addition, in Fig. $4 \mathrm{~d}$ grains can be seen embedded in the $\gamma$ phase that were indexed by EBSD as unreacted Mg. These grains disappeared from the reaction layer with longer heat treatment times. 

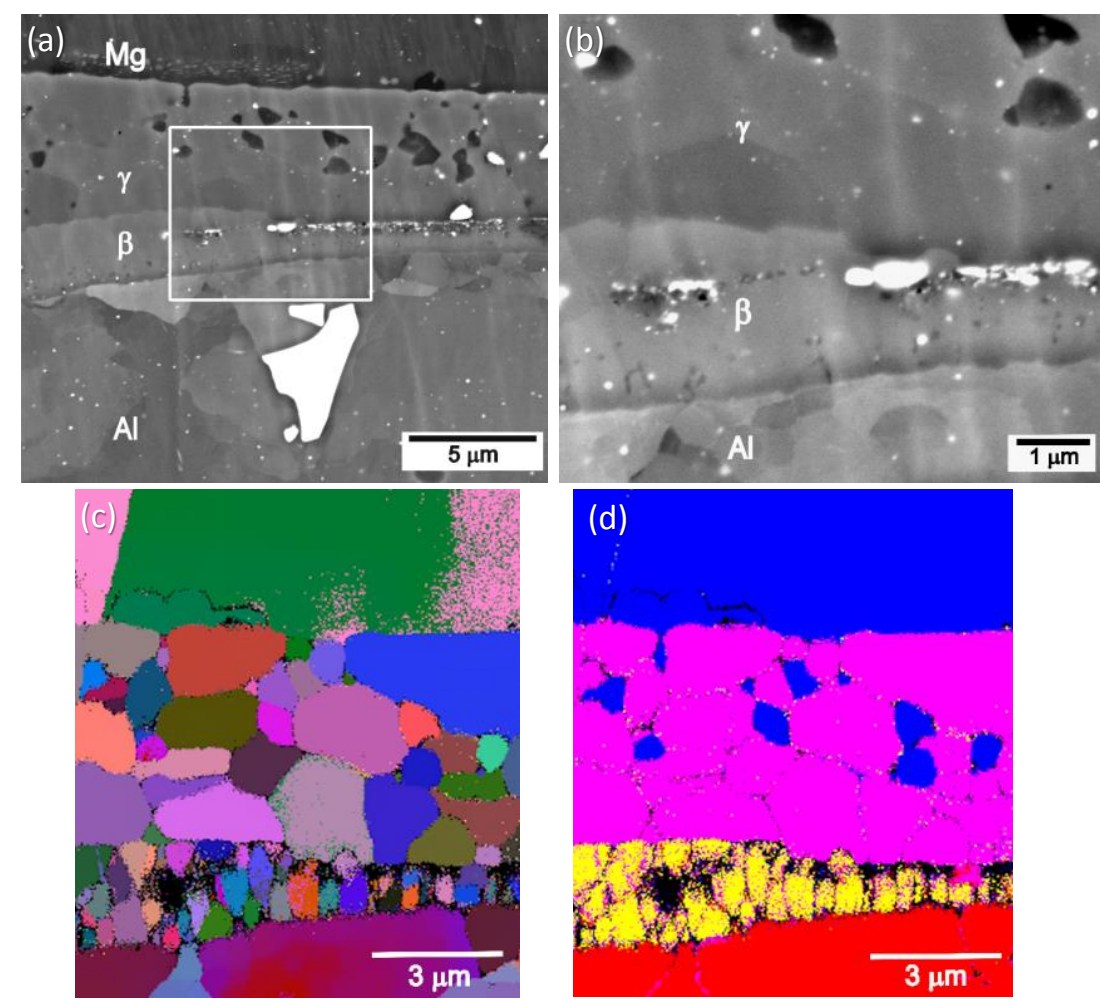

Fig. 4 Interfacial morphology of an $\mathrm{Al}-\mathrm{Mg}$ sample after a short heat treatment of 5 minutes at 400 ${ }^{\circ} \mathrm{C}$ : (a) BSE micrograph of the interfacial area; (b) enlarged BSE micrograph from the dashed box in (a); (c) and (d) Euler angle and phase maps, respectively, obtained by EBSD analysis.

\section{Longer Reaction Times}

Examples of the $\mathrm{Al}-\mathrm{Mg}$ interface region seen following isothermal heat treatment for $24 \mathrm{hrs}$ at 400 ${ }^{\circ} \mathrm{C}$ are illustrated in Fig. 5. After this longer heat-treatment, two uniformly thick IMC sublayers can be observed. By using EBSD and EDX analysis, the thinner upper intermetallic layer was indexed as the $\gamma-\mathrm{Al}_{12} \mathrm{Mg}_{17}$ phase and the thicker lower layer as $\beta-\mathrm{Al}_{3} \mathrm{Mg}_{2}$ (Fig. 5c), which is in agreement with previous observations $[2,14-18,20]$. The intermetallic reaction layer at the edge of the original weld zone is also illustrated in Fig. 6. Outside the weld zone, where no metallurgical bond was formed, the two alloys have remained largely unreacted. Using this reference for the original interface position, it can be clearly seen that the IMC sublayers grew into both parent materials during heat treatment and the faster growing $\beta$ phase is also consuming the $\gamma$ phase. 

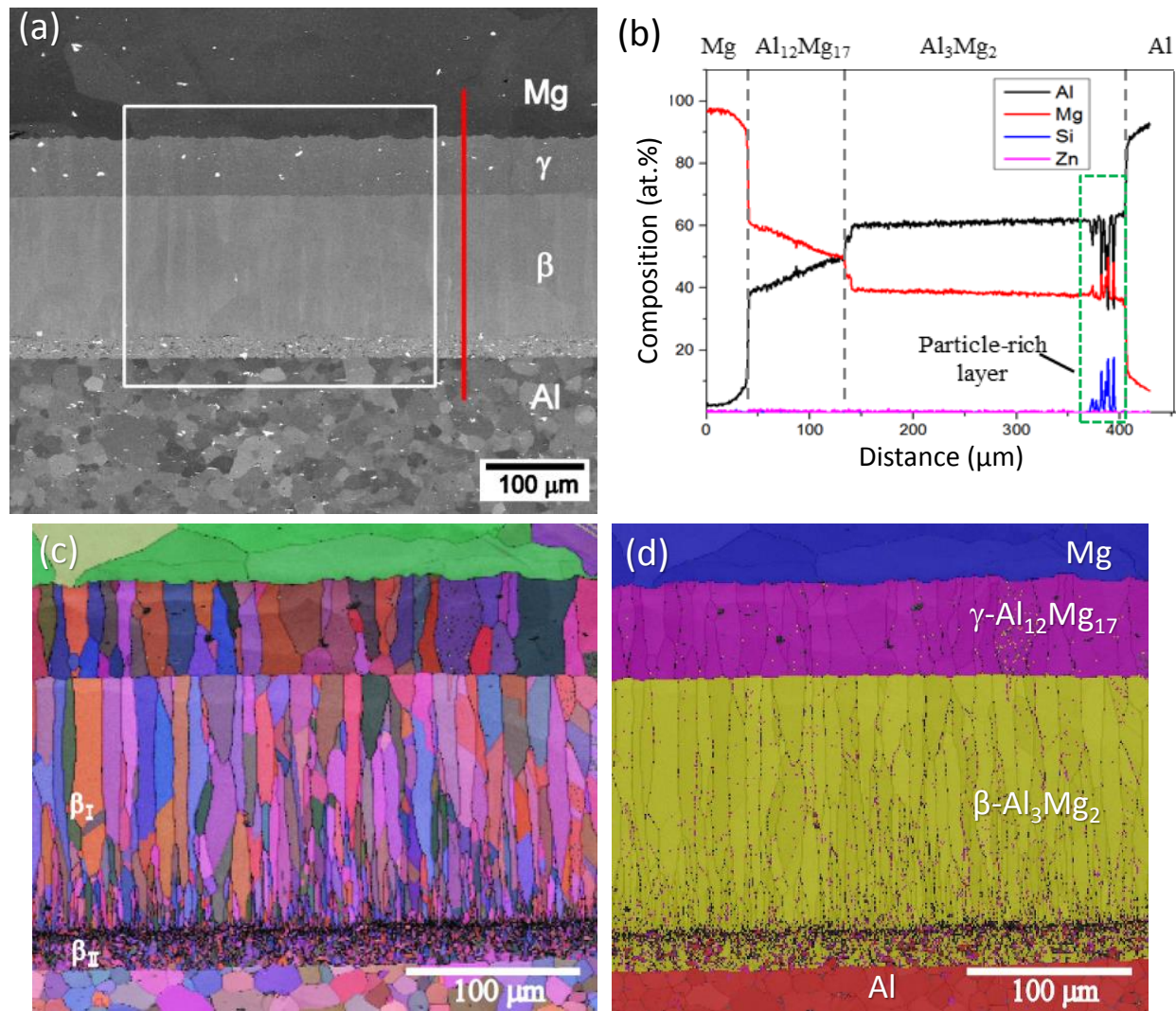

Fig. 5 The interfacial morphology of an $\mathrm{Al}-\mathrm{Mg}$ sample after long-term heat treatment at $400{ }^{\circ} \mathrm{C}$ for $24 \mathrm{~h}$ : (a) BSE micrograph of the interfacial area, (b) EDX composition analysis along the red line in (a), (c) and (d) an Euler angle and phase maps, respectively, obtained by EBSD mapping the white box in (a).

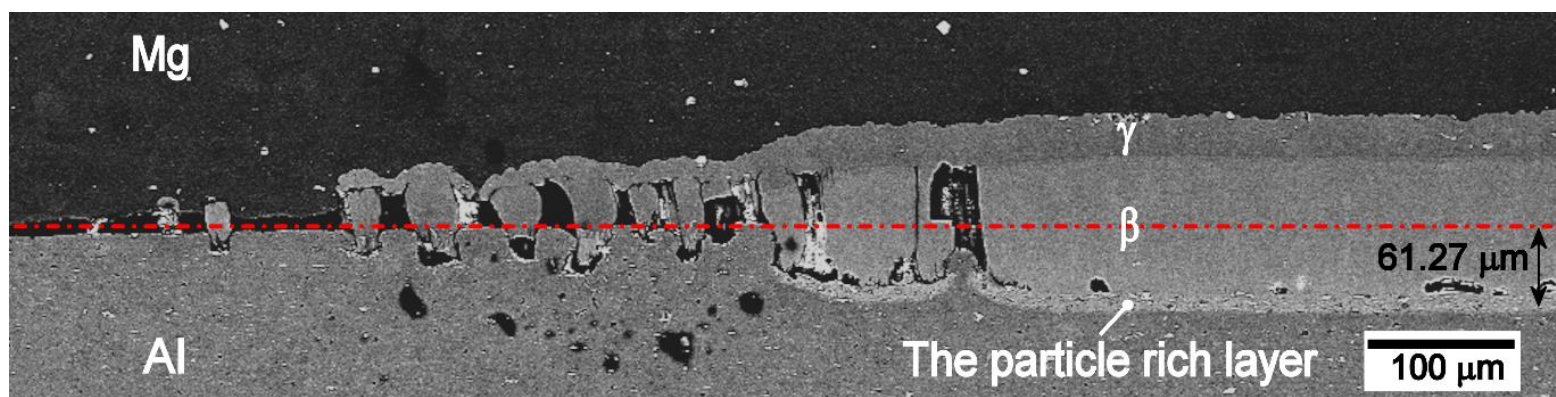

Fig. 6 SEM micrograph showing the edge of the reaction area in the couple annealed at $360{ }^{\circ} \mathrm{C}$ for $24 \mathrm{hrs}$.

From the Euler angle contrast orientation map in Fig. 5c, it can be see that with a longer reaction time both IMC sub-layers have developed larger columnar grains, oriented normal to the diffusion direction, as previously reported [20]. In addition, within the $\beta-\mathrm{Al}_{3} \mathrm{Mg}_{2}$ layer, two sub-layers were discernible: an upper layer (marked $\beta_{\mathrm{I}}$ ) that accounted for most of the total IMC thickness with a 
columnar grain structure, that was largely free of second phase particles, and a lower thinner layer about $30 \mu \mathrm{m}$ thick (marked $\beta_{\text {II }}$ ) composed of fine sub-micron equiaxed grains, which contained a high concentration of second phase particles (Fig. 5a). From the appearance of these grain structures, it seems reasonable to assume that $\mathrm{Al}_{3} \mathrm{Mg}_{2}-\beta$ grains nucleate at the interface with the $\mathrm{Al}$ substrate and then undergo directional growth becoming preferentially aligned in the direction normal to the interface. However, no fine grained nucleation zone was identified either at the $\mathrm{Al}_{3} \mathrm{Mg}_{2} / \mathrm{Al}_{12} \mathrm{Mg}_{17}$ interface, or the $\mathrm{Al}_{12} \mathrm{Mg}_{17} / \mathrm{Mg}$ interface. This suggests that the $\gamma-\mathrm{Al}_{12} \mathrm{Mg}_{17}$ phase only nucleates at the start of the reaction before $\beta$ forms and then once nucleated the grains grows into the $\mathrm{Mg}$ substrate, while evidence of their earlier development is wiped out by the $\beta$ phase when it subsequently appears and overgrows $\gamma$. The grain structures across the $\mathrm{Al}_{3} \mathrm{Mg}_{2} / \mathrm{Al}_{12} \mathrm{Mg}_{17}$ interface also suggest that $\beta-\mathrm{Al}_{3} \mathrm{Mg}_{2}$ forms directly from $\gamma-\mathrm{Al}_{12} \mathrm{Mg}_{17}$ by a structural transformation at the $\mathrm{Al}_{3} \mathrm{Mg}_{2} / \mathrm{Al}_{12} \mathrm{Mg}_{17}$ interface. However, no obvious alignment of the grains or grain boundaries could be observed between the two phases at the growth front.

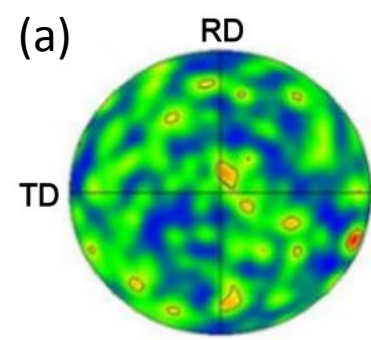

$\{100\}$

(b)

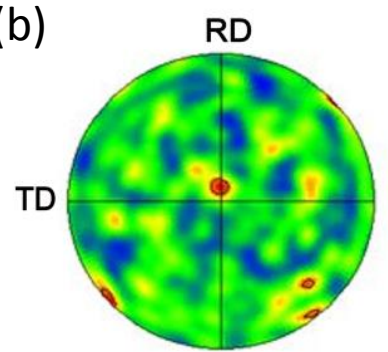

$\{100\}$

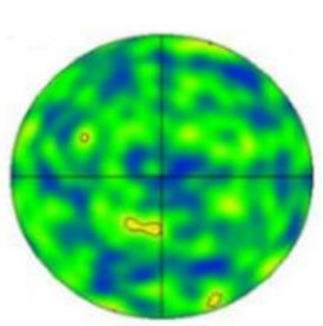

$\{110\}$

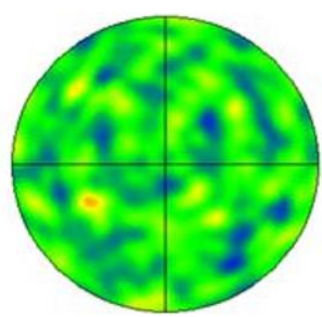

$\{110\}$

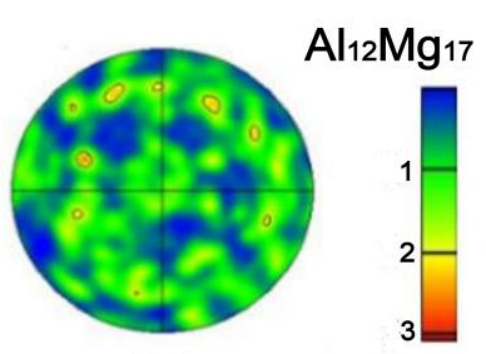

$\{111\}$

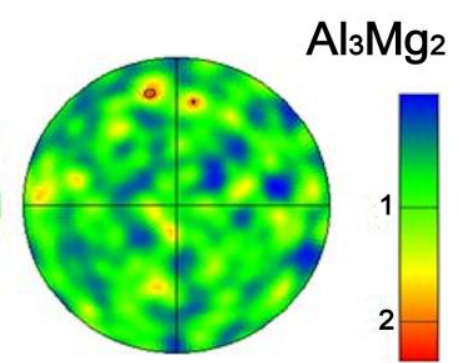

$\{111\}$

Fig. 7100,110 and 111 pole figures measured by EBSD from the (a) $\gamma-\mathrm{Al}_{12} \mathrm{Mg}_{17}$ and (b) $\beta-\mathrm{Al}_{3} \mathrm{Mg}_{2}$ IMC phases in an AA6111 - AZ31 sample annealed at $400{ }^{\circ} \mathrm{C}$ for $24 \mathrm{hrs}$.

\section{Grain Orientations in the IMC Layers}

As shown in Fig. 5, both reaction layers in the sample heat-treated at $400{ }^{\circ} \mathrm{C}$ for 24 hours contained columnar grains aligned normal to the weld line, which suggests a preferential crystallographic growth direction. EBSD data was therefore used to investigate the texture of the $\gamma-\mathrm{Al}_{12} \mathrm{Mg}_{17}$ and $\beta-\mathrm{Al}_{3} \mathrm{Mg}_{2}$ IMC layers and pole figures for the two phases are provided in Fig. 7. Approximately 300 
$\gamma$ and $800 \beta$ grains were included in the analysis, giving reasonable statistics. However, despite the columnar grain morphology, the pole figures indicate that the texture of both phases was essentially random. These results thus show that both phases grew with no preferred crystallographic orientation and the columnar grain structures observed are simply caused by the one dimensional growth direction. This observation contradicts work by Dietrich et al. [20] who have reported that the $\gamma-\mathrm{Al}_{12} \mathrm{Mg}_{17}$ phase formed in an $\mathrm{Al}-\mathrm{Mg}$ diffusion couple heat-treated at a similar temperature $\left(430{ }^{\circ} \mathrm{C}\right.$ ) had a weak $\{111\}$ fiber orientation. The coarser gain size seen in their work [20] and the more limited number of grains analyzed may be a possible explanation for the lack of agreement between these two sets of results.

\subsection{Growth Kinetics of the $\mathrm{Al}_{12} \mathrm{Mg}_{17} / \mathrm{Al}_{3} \mathrm{Mg}_{2}$ Bi-Layers}

The relationship between the thickness of a continuous IMC layer $(x)$ and annealing time $(t)$ at a constant temperature is commonly described by the one-dimensional kinetic equation [5]:

$$
x^{n}=k t \quad \text { Equation } 1
$$

where $n$ is the kinetic exponent, and $k$ the rate constant.

Fig. 8 a and b show logarithmic plots of the thicknesses of the $\gamma$ and $\beta$ layers measured in this study against annealing time at three temperatures, $360{ }^{\circ} \mathrm{C}, 400{ }^{\circ} \mathrm{C}$ and $420{ }^{\circ} \mathrm{C}$. The data can be seen to exhibit slopes very close to, but slightly below, the ideal gradient of 0.5 for parabolic growth. Both IMC phases therefore have an exponent close to that expected for one dimensional diffusion-controlled growth, as has been reported [10-13, 20].

The rate constant $k$ can be described by the Arrhenius equation [10]:

$$
k=k_{0} \exp \left(-\frac{Q}{R T}\right) \quad \text { Equation } 2
$$

where $k_{0}$ denotes the pre-exponential factor, $Q$ the activation energy of growth, and $R$ the gas constant.

The growth constants for each phase, $k_{0}$ and $Q$, have also been determined from regression fit in $\ln (k)$ versus $\mathrm{T}^{-1}$ plots in Fig. $8 \mathrm{c}$ and $\mathrm{d}$ and the values are compared to a review of kinetic data taken form the literature in Table 2, showing close agreement with published results for unalloyed $\mathrm{Al}$ and 
Mg. This suggests that the growth kinetics of the IMC phases were insignificantly affected by the alloying elements present in the AA6111 and AZ31 alloys employed in this study.

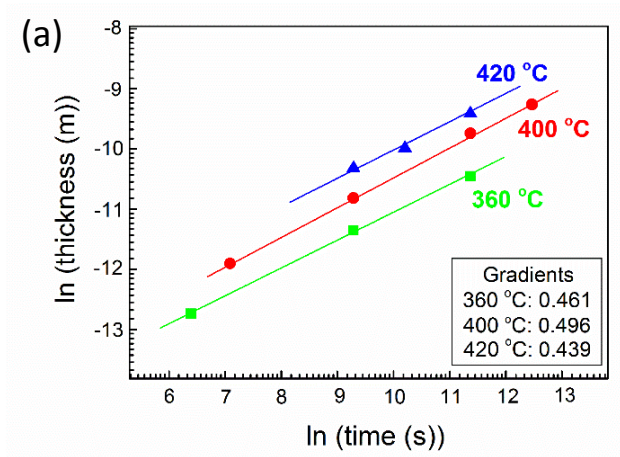

(c)

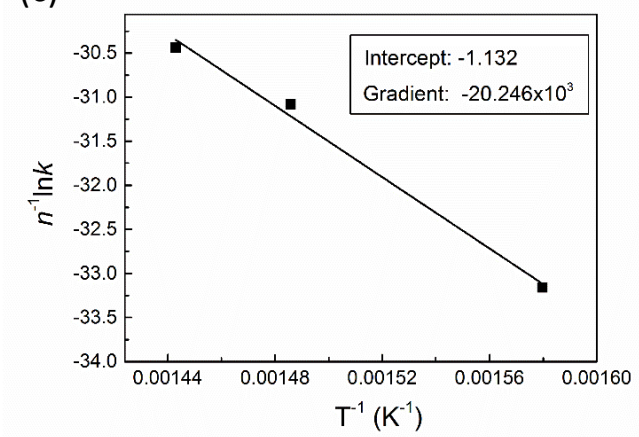

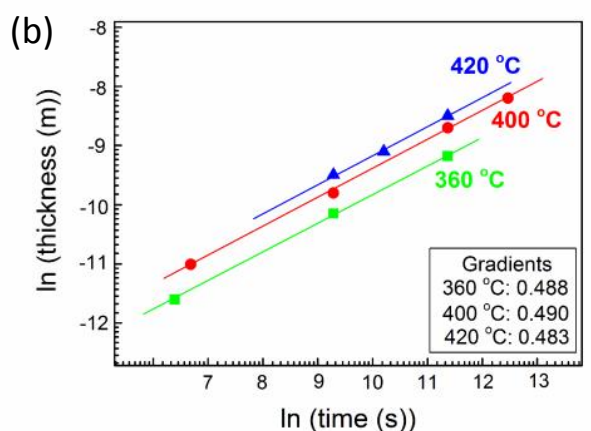

(d)

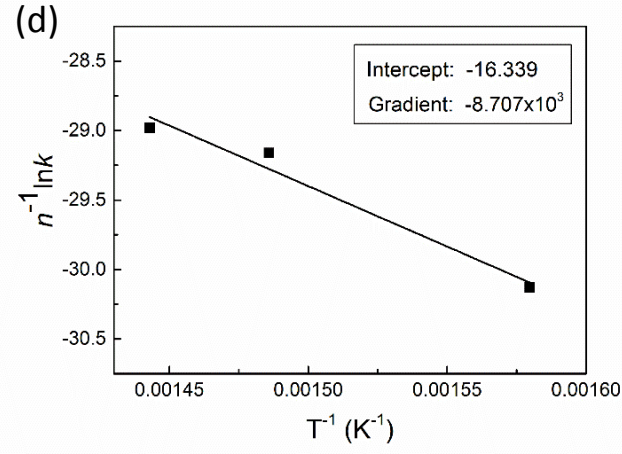

Fig. 8 Experimental IMC layer thickening rate data obtained from the static heat treatments, showing in; (a) and (b) Plots of $\ln (\Delta \mathrm{x})$ versus $\ln (\mathrm{t})$ for the $\gamma-\mathrm{Al}_{12} \mathrm{Mg}_{17}$ and $\beta-\mathrm{Al}_{3} \mathrm{Mg}_{2}$ phases, respectively, and in (c) and (d) the temperature dependence of $\ln (\mathrm{t})$ for the $\mathrm{Al}_{12} \mathrm{Mg}_{17}$ and $\mathrm{Al}_{3} \mathrm{Mg}_{2}$ phases, respectively.

Table 2 Comparison of kinetic rate constants for one-dimensional growth of the main Al-Mg IMC phases measured in the current study with data compiled from the literature.

\begin{tabular}{cccc}
\hline Phase & $k_{0}\left(\mathrm{~m}^{2} / \mathrm{s}\right)$ & $Q(\mathrm{~kJ} / \mathrm{mol})$ & Reference \\
\hline & $8.01 \times 10^{-8}$ & 72 & Current Study \\
$\beta$ & $3.5 \times 10^{-8}$ & 69 & {$[10]$} \\
& $5.3 \times 10^{-8}$ & 67 & {$[11$} \\
& $2.2 \times 10^{-8}$ & 57 & {$[13]$} \\
\hline & 0.32 & 168 & Current Study \\
$\gamma$ & 0.1 & 165 & {$[10]$} \\
& $3.4 \times 10^{-2}$ & 142 & {$[11]$} \\
\hline Entire IMC layer & 0.4 & 106 & {$[2]$} \\
\hline
\end{tabular}




\section{Kirkendall Effects}

As mentioned above, the $\beta-\mathrm{Al}_{3} \mathrm{Mg}_{2}$ phase consisted of two sub-layers; $\beta_{1}$, which was columnar grained, and $\beta_{\text {II }}$ adjacent to the Al base material, which contained fine equiaxed grains (Fig. 5 and 6). A large volume fraction of coarse second phase particles was found in the $\beta_{\text {II }}$ sublayer, which have been magnified in Fig. 9. Two types of particle can be observed with different $Z$ contrast in the BSE images. From EDX analysis (Table 3), the bright white particles were found to contain $\mathrm{Fe}, \mathrm{Mn}$, and $\mathrm{Si}\left(\sim 15,2.5\right.$ and 1.1 at. \%, respectively), suggesting that they are either $\alpha-\mathrm{Al}_{12}(\mathrm{FeMn})_{3} \mathrm{Si}$, or $\beta-\mathrm{Al}_{9}(\mathrm{FeMn})_{2} \mathrm{Si}_{2}$, two of the main constituent ternary phases known in the AA6111 alloy [29]. The darker gray particles, however, contained mainly Si and $\mathrm{Mg}(\sim 24$ and 55 at. \%, respectively), indicating that they are probably $\mathrm{Mg}_{2} \mathrm{Si}$ that has coarsened during prolonged heat treatment at $400{ }^{\circ} \mathrm{C}$, which is below the $\mathrm{Mg}_{2} \mathrm{Si}$ solvus. The increase in Si content in this layer is also reflected in the EDX line scan results in Fig. 5b. By comparison with the Al base alloy (e.g. Fig. 5a) it can be seen that both types of particle are largely similar, in terms of their morphology and size, but their inter-particle spacing has been greatly compressed within the IMC layer. In contrast, second phase particles were very rarely seen in the $\beta_{\text {I }}$ sublayer.

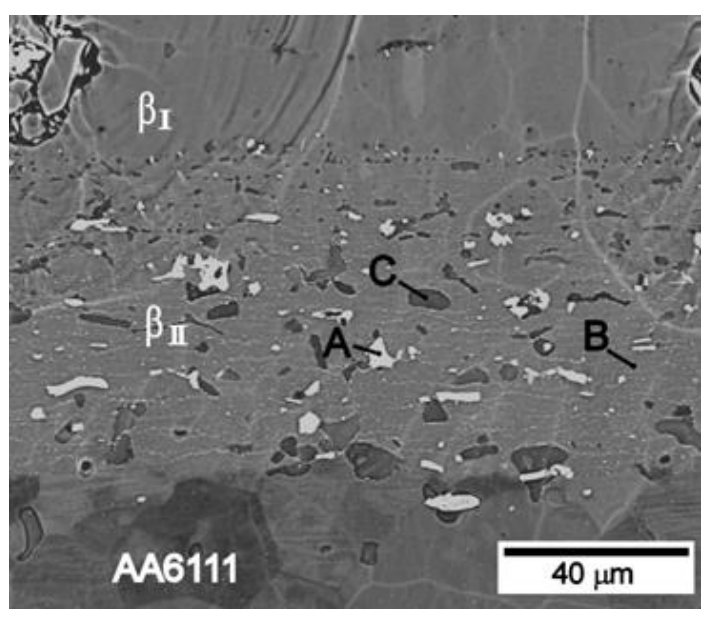

Fig. $9 \mathrm{BSE}$ image of the particle-rich $\beta_{\mathrm{II}}$ sublayer after annealing at $400{ }^{\circ} \mathrm{C}$ for $72 \mathrm{hrs}$.

Table 3 Typical compositions measured by EDX (in at\%) from the second phase particles found in the $\beta_{\text {II }}$ sublayer after annealing at $400{ }^{\circ} \mathrm{C}$ for $72 \mathrm{hrs}$ and the matrix at the positions (A-C) marked in Fig. 9.

\begin{tabular}{cccccccccc}
\hline & $\mathrm{Al}$ & $\mathrm{Mg}$ & $\mathrm{Si}$ & $\mathrm{Fe}$ & $\mathrm{Cu}$ & $\mathrm{Mn}$ & $\mathrm{Ti}$ & $\mathrm{Zn}$ & $\mathrm{C}$ \\
\hline $\mathrm{A}$ & 78.4 & 2.6 & 1.1 & 15.3 & - & 2.5 & - & 0.1 & - \\
$\mathrm{B}$ & 58.5 & 35.9 & - & 0.1 & 0.9 & 0.2 & 0.1 & 0.1 & 4.2 \\
$\mathrm{C}$ & 16.7 & 54.9 & 23.7 & 0.1 & 0.1 & 0.2 & - & - & 4.3 \\
\hline
\end{tabular}


In Fig. 10, the interfacial region of the AA6111-AZ31 couple is compared to that with an identically prepared pure $\mathrm{Al}$-AZ31 sample, following the same heat treatment. An identical thickness IMC reaction layer, consisting of $\gamma-\mathrm{Al}_{12} \mathrm{Mg}_{17}$ and $\beta-\mathrm{Al}_{3} \mathrm{Mg}_{2}$ sublayers can be seen in both samples, which suggests that the presence of second phase particles and alloy composition in this system has minimal effect on the IMC growth rate. However, in the pure Al sample (Fig. 10b) a row of voids is apparent in the location corresponding to the particle-rich layer in the joint prepared with the AA6111 alloy (Fig. 10a). Mass transport of Al as it is consumed by the reaction process can thus have two effects: i) the formation of Kirkendall voids (seen predominantly in the pure Al couple), and ii) compression of the spacing of the particles left behind as the Al matrix was consumed. The concentration of particles within diffusion couples has also been observed in other studies [20, 30]. This high density of second phase particles will have contributed to the retention of the finer equiaxed grain structure seen in the $\beta_{11}$ sublayer. Relatively few Kirkendall voids were also found in the sample produced with the AA6111 alloy. This in turn can be attributed to a higher site density for vacancy annihilation related to the large number of second phase particles and fner grain size within the 6111 sample, which must be sufficient to inhibit the nucleation of voids by vacancy condensation.
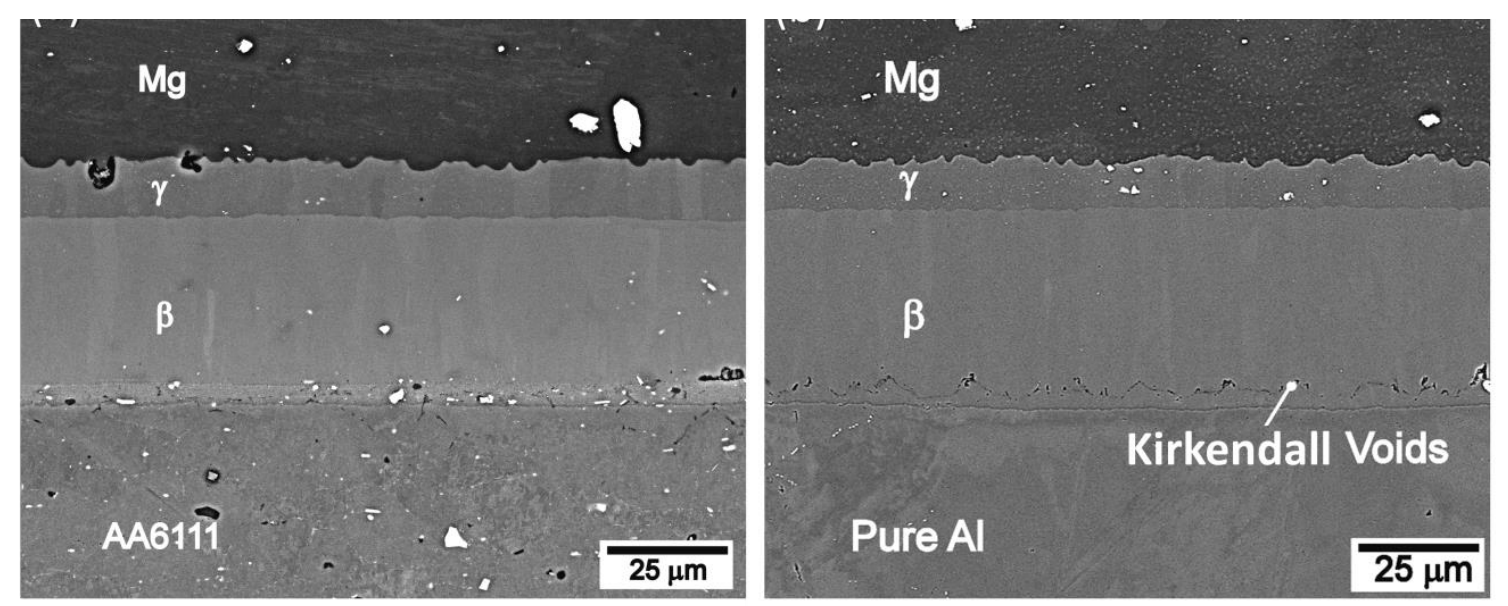

Fig 10. Interfacial microstructures of (a) the AA6111 - AZ31 and (b) the pure Al - AZ31 interdiffusion samples, after heat-treatment for 3 hours at $360{ }^{\circ} \mathrm{C}$.

\section{Interdiffusion Coefficients}

The concentration of constituent particles within the $\beta$ phase can be exploited as diffusion markers to determine the migration rate of the Kirkendall plane by quantifying their compression normal to 
the interface. The Kirkendall plane in the $\beta$ phase can be conveniently identified from the boundary between the particle-rich and particle free layers. Its displacement was determined by using image analysis to compare the average ratio of the particle area fraction, per unit thickness, in the AA6111 substrate material to that in the $\beta$-phase particle rich layer. Using this data, and EDX measurements across the interface (e.g. Fig. 5b) the intrinsic diffusion coefficients $\left(\mathrm{D}_{\mathrm{i}}\right)$ could be estimated for $\mathrm{Al}$ and $\mathrm{Mg}$ in the $\beta$ phase, using the Boltzmann-Matano analysis [31, 32]:

$$
D_{i}=-\frac{\int_{C_{i}^{ \pm \infty}}^{C_{i}^{x_{k}}} x \mathrm{~d} C_{i}}{2 t\left[\frac{\partial C_{i}}{\partial x}\right]_{x_{k}}} \quad(i=\mathrm{Mg} \text { or } \mathrm{Al}) \quad \text { Equation } 3
$$

where $x$, is distance, $x_{\mathrm{k}}$, the location of the Kirkendall plane, $t$, the diffusion time, $C_{i}^{x_{k}}$ the concentration of the $i^{\text {th }}$ component at the Kirkendall plane, and $C_{i}^{ \pm \infty}$ the concentration at the terminal ends of the IMC layers, obtained by EDX (e.g. Fig.5b).

The intrinsic diffusion coefficients of $\mathrm{Al}$ and $\mathrm{Mg}$ in the $\beta \mathrm{Al}_{3} \mathrm{Mg}_{2}$ phase estimated using this procedure and Equation 3 are shown in Table 4. Close agreement can be seen with values reported by Brennan et al. [32], at similar temperatures. Overall, this analysis shows that Al diffuses more rapidly than $\mathrm{Mg}$ by an order of magnitude at typical temperatures for friction welding $\left(350-437{ }^{\circ} \mathrm{C}\right)$ $[33,34]$. This indicates that any measures that can retard the diffusion of $\mathrm{Al}$ through the $\beta$ phase will be more efficient in inhibiting rapid IMC growth.

Table 4 Intrinsic diffusion coefficients for $\mathrm{Al}$ and $\mathrm{Mg}$ in the $\beta$ phase obtained from the current study compared to published literature.

\begin{tabular}{ccc}
\hline & \multicolumn{1}{c}{ Intrinsic Diffusion Coefficients } \\
$D_{\mathrm{Al}}$ & $D_{\mathrm{Mg}}$ & \multirow{2}{*}{ Ref. } \\
\cline { 1 - 3 }$\left(\mathrm{m}^{2} / \mathrm{s}\right)$ & $\left(\mathrm{m}^{2} / \mathrm{s}\right)$ & {$[32]$} \\
\hline $8.8 \times 10^{-14}\left(350^{\circ} \mathrm{C}\right)$ & $3.9 \times 10^{-15}\left(350^{\circ} \mathrm{C}\right)$ & Current study \\
$9.10 \times 10^{-14}\left(360^{\circ} \mathrm{C}\right)$ & $3.43 \times 10^{-15}\left(360^{\circ} \mathrm{C}\right)$ & {$[32]$} \\
$2.9 \times 10^{-13}\left(400^{\circ} \mathrm{C}\right)$ & $1.9 \times 10^{-14}\left(400^{\circ} \mathrm{C}\right)$ & \\
\hline
\end{tabular}

\subsection{The $\varepsilon-\mathrm{Al}_{30} \mathrm{Mg}_{23}$ Phase}

In samples heat treated for very long times (e.g. $400{ }^{\circ} \mathrm{C}$ for 72 hours) a third IMC layer was observed to develop at the interface between the $\gamma-\mathrm{Al}_{12} \mathrm{Mg}_{17}$ and $\beta-\mathrm{Al}_{3} \mathrm{Mg}_{2}$ phases (Fig. 11b). However, a similar layer was also subsequently found in samples subject to less severe heat treatments (e.g. $360{ }^{\circ} \mathrm{C}$ for 24 hours; Fig. 11a). This new IMC layer remained relatively thin and 
was composed of grains a single row thick, which were elongated in the interface plane (Fig. 11). Despite obtaining good band contrast, the new phase could not be identified in EBSD maps as indexing was impeded by its complex Kikuchi patterns, which is indicative of low symmetry crystal structure. To identify the new phase, a FIB sample was therefore milled out across all three IMC layers for TEM characterization (Fig. 12). In the TEM-EDX line scan along the line shown in Fig. $12 \mathrm{~b}$ the mid IMC layer exhibits a distinctive compositional plateau of 45 at. $\% \mathrm{Mg}$, (i.e. close to $\left.\mathrm{Al}_{5} \mathrm{Mg}_{4}\right)$ which is in line with the reported stoichiometry of the controversial $\varepsilon$ phase $\left(\mathrm{Al}_{30} \mathrm{Mg}_{23}\right)[8$, 9]. According to the recalculation of the central part of the Al-Mg phase diagram by $\mathrm{Su}$ et al. [9] (Fig. 1), $\varepsilon$ can form within the temperature range of 250 to $410^{\circ} \mathrm{C}$.

The $\varepsilon-\mathrm{Al}_{30} \mathrm{Mg}_{23}$ phase has been proposed by Samson to have a rhombohedral space group $\mathrm{R}-3 \mathrm{H}(148)$, with lattice parameters $\mathrm{a}=\mathrm{b}=12.8254 \AA$, $\mathrm{c}=21.7478 \AA, \alpha=\beta=90^{\circ}$, and $\gamma=120^{\circ}$ [35]. Using this crystal system, selected area diffraction patterns from the new phase gave a satisfactory match to three low-index zone axes, [001], [110] and [02̄1], as shown in Fig. 12 d-e. Although the $\varepsilon-\mathrm{Al}_{30} \mathrm{Mg}_{23}$ phase has been synthesized by applying very long term heat-treatments to Al-Mg alloys cast with its stoichiometric composition [9, 35], it has not been previously reported in $\mathrm{Al}-\mathrm{Mg}$ diffusion couples, or dissimilar welds.

In stoichiometric alloys the formation of $\varepsilon$ has been reported to be extremely sluggish, with no trace of the phase found after 50 hours at $350{ }^{\circ} \mathrm{C}$, or 170 hours at $380{ }^{\circ} \mathrm{C}[9,35]$. In comparison, although unlikely to appear under conventional welding conditions, here $\varepsilon-\mathrm{Al}_{30} \mathrm{Mg}_{23}$ was found to form far more rapidly. For example, Fig. 11 shows a continuous layer of $\varepsilon-\mathrm{Al}_{30} \mathrm{Mg}_{23}$ already present at the $\mathrm{Al}_{12} \mathrm{Mg}_{17} / \mathrm{Al}_{3} \mathrm{Mg}_{2}$ interface, after heat-treatment for only 24 hours at $360{ }^{\circ} \mathrm{C}$. The mechanism of formation of $\varepsilon$ is currently unclear, but it probably does not form by direct transformation of either $\mathrm{Al}_{12} \mathrm{Mg}_{17}$ or $\mathrm{Al}_{3} \mathrm{Mg}_{2}$ as there is no correspondence of the grain orientations in the EBSD data. This would infer a diffusion controlled growth process with an incoherent interface. 

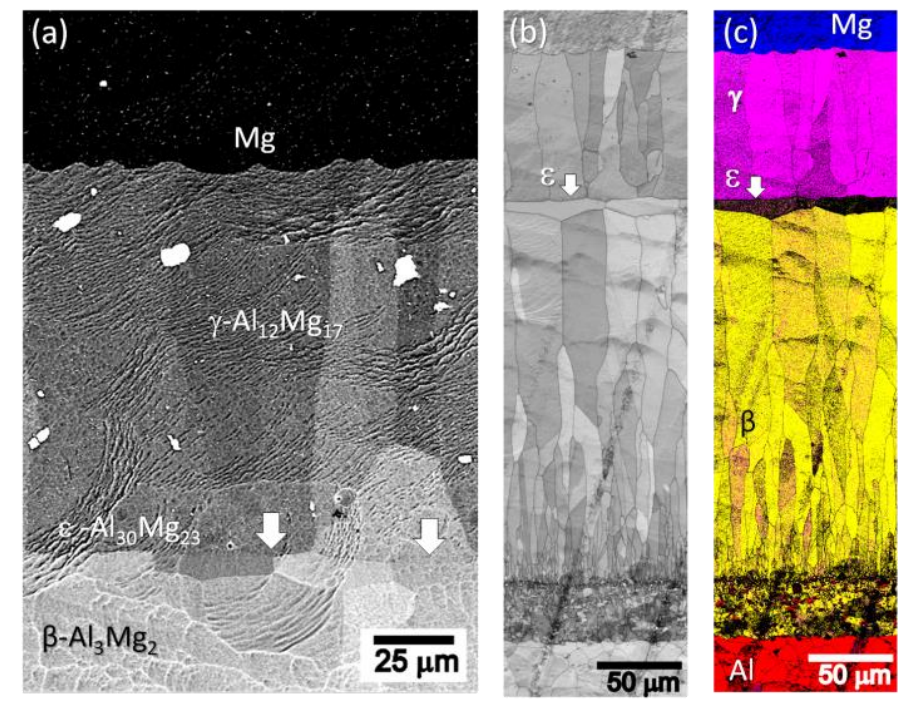

Fig. 11 The $\varepsilon$ phase in $\mathrm{Al}-\mathrm{Mg}$ diffusion couples at the interface between the $\beta$ and $\gamma$ IMC layers after longer-term heat treatment; (a) BSE micrograph after 24 hours at $360{ }^{\circ} \mathrm{C}$; (b) and (c) EBSD band contrast and phase maps obtained by EBSD analysis of a sample after 72 hours at $400{ }^{\circ} \mathrm{C}(\varepsilon$ is indicated by arrows). 

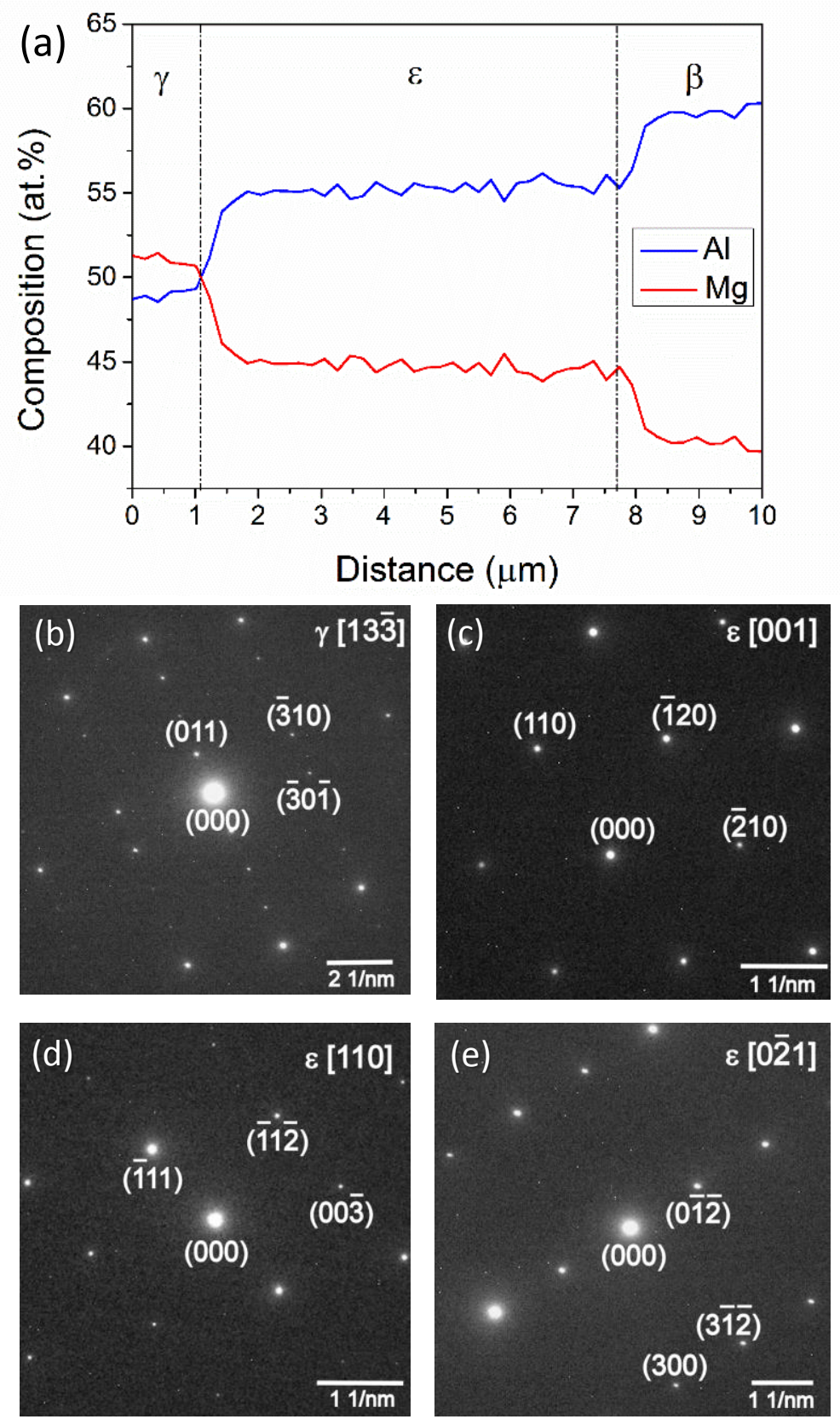

Fig. 12 TEM characterization of the $\varepsilon$ phase in an $\mathrm{Al}-\mathrm{Mg}$ couple annealed at $400{ }^{\circ} \mathrm{C}$ for 72 hours; (a) an EDX line scan profile across the interface between the $\beta$ and $\gamma$ phase; (b) a diffraction pattern taken from the $\gamma$ phase and (c) - (e), diffraction patterns showing different zone axes indexed as $\varepsilon-\mathrm{Al}_{30} \mathrm{Mg}_{23}$.

\subsection{Mechanical Properties of the IMC Phases}

The IMCs in the Al-Mg system are characteristically extremely brittle. In mechanical tests performed on dissimilar welds this typically manifests itself in low strength joints that fail by crack propagation in the IMC reaction layer with poor energy absorption [2-5]. In addition, in Fig.13 it can be seen that fracture normally propagates in the thicker $\beta-\mathrm{Al}_{3} \mathrm{Mg}_{2}$ sublayer across the joint 
interface. It is therefore desirable to assess the mechanical properties, and in particular the fracture toughness, of the two major IMC phases formed in Al-Mg welds (i.e. $\gamma$ and $\beta$ ).

Microhardness tests conducted on the $\beta$ and $\gamma$ phases in samples with thick IMC layers after long reaction times gave average values for $\gamma-\mathrm{Al}_{12} \mathrm{Mg}_{17}$ and $\beta-\mathrm{Al}_{3} \mathrm{Mg}_{2}$ in the range of $260-290 \mathrm{HV}$. The hardness levels and Young's moduli of all three IMCs, $\gamma, \beta$ and $\varepsilon$, were also determined by nano-indentation. All the results are summarized in Table 5 and show reasonable agreement with published values, except for the hardness of the $\beta$ phase which is lower than published in ref [20]. Of the three $\mathrm{Al}-\mathrm{Mg}$ IMCs identified, $\beta-\mathrm{Al}_{3} \mathrm{Mg}_{2}$ can be seen to have the highest hardness, followed by $\gamma-\mathrm{Al}_{12} \mathrm{Mg}_{17}$, with the lowest values measured for $\varepsilon-\mathrm{Al}_{30} \mathrm{Mg}_{23}$, while $\gamma$ has the highest Young's modulus.

Table 5 The mechanical properties of the Al-Mg IMC phases measured in this work (bold) compared to published values for Al-Mg, as well as to other common aluminide phases compiled from the literature.

\begin{tabular}{|c|c|c|c|c|c|}
\hline & & $\mathrm{Al}-\mathrm{Mg} \mathrm{IMCs}$ & & $\mathrm{TT} \wedge 1$ & $\mathrm{E}_{0} \mathrm{1}$ \\
\hline & $\beta-\mathrm{Al}_{3} \mathrm{Mg}_{2}$ & $\gamma-\mathrm{Al}_{12} \mathrm{Mg}_{17}$ & $\varepsilon-\mathrm{Al}_{30} \mathrm{Mg}_{23}$ & $11 \mathrm{Al}_{3}$ & $\mathrm{FeAl}_{3}$ \\
\hline \multirow{3}{*}{$\begin{array}{l}\text { Micro-Hardness } \\
\qquad\left(\mathrm{H}_{\mathrm{V}}\right)^{a}\end{array}$} & \multirow{3}{*}{$\begin{array}{c}\mathbf{2 8 9 . 4} \pm \mathbf{3 . 6} \\
370[20]\end{array}$} & $268.3 \pm 3.6$ & \multirow{3}{*}{-} & \multirow{3}{*}{$600[38]$} & \multirow{3}{*}{$\begin{array}{l}691[39] \\
892[40]\end{array}$} \\
\hline & & $265[36]$ & & & \\
\hline & & 253 [37] & & & \\
\hline \multirow{3}{*}{$\begin{array}{l}\text { Nano-Hardness } \\
(\mathrm{GPa})^{b}\end{array}$} & \multirow{3}{*}{$\begin{array}{c}\mathbf{4 . 0 9} \pm \mathbf{0 . 1 0} \\
4.35[41]\end{array}$} & $3.82 \pm 0.18$ & \multirow{3}{*}{$3.39 \pm 0.03$} & o & \multirow{3}{*}{$10.5[44]$} \\
\hline & & $5.18[36]$ & & $\begin{array}{c}9.2[42] \\
9[43]\end{array}$ & \\
\hline & & $4.4[41]$ & & & \\
\hline \multirow{5}{*}{$\mathrm{E}(\mathrm{GPa})$} & $63.49 \pm 1.27$ & $71.95 \pm 4.54$ & \multirow{5}{*}{$58.75 \pm 0.40$} & & \multirow{5}{*}{284 [39] } \\
\hline & $60[20]$ & $70[20]$ & & & \\
\hline & $53.8[45]$ & $71[36]$ & & $\begin{array}{l}141[38] \\
220[42]\end{array}$ & \\
\hline & 66.8 [41] & $78[47]^{c}$ & & & \\
\hline & $49.8[46]^{c}$ & $79.6[48]^{c}$ & & & \\
\hline \multirow{3}{*}{$\mathrm{K}_{\mathrm{IC}}\left(\mathrm{MPam}^{1 / 2}\right)$} & \multirow{3}{*}{$0.062^{d}$} & $0.105^{d}$ & \multirow{3}{*}{ - } & \multirow{3}{*}{2 [49] } & \multirow{3}{*}{0.967 [39] } \\
\hline & & $0.27-0.37[36]^{d}$ & & & \\
\hline & & $0.38-0.53[36]^{e}$ & & & \\
\hline
\end{tabular}

${ }^{a}$ Measured by microhardness tests; ${ }^{b}$ measured by nanoindentation tests; ${ }^{c}$ from theoretical calculations; ${ }^{d}$ calculated using crack lengths parallel to the interface only; ${ }^{e}$ Calculated using crack lengths parallel and normal to the interface plane.

The fracture toughness of a brittle material can be estimated from the cracks developed in a pyramidal indentation test, using the expression $[27,50]$

$$
K c=\alpha\left(\frac{E}{H}\right)^{1 / 2} \frac{F}{c^{3 / 2}}, \quad(\text { Equation } 3)
$$


Where $K \mathrm{c}$ is the fracture toughness, $\alpha$, is a constant that has been calibrated to be $0.016 \pm 0.004$ by Anstis et al. [27], $E$, is Young's modulus, $H$, is the Vickers hardness value, $F$, is the peak load applied during micro-indentation $(0.5 \mathrm{~N})$, and $c$ is the length of a radial crack extending from the corner of an indenter impression.

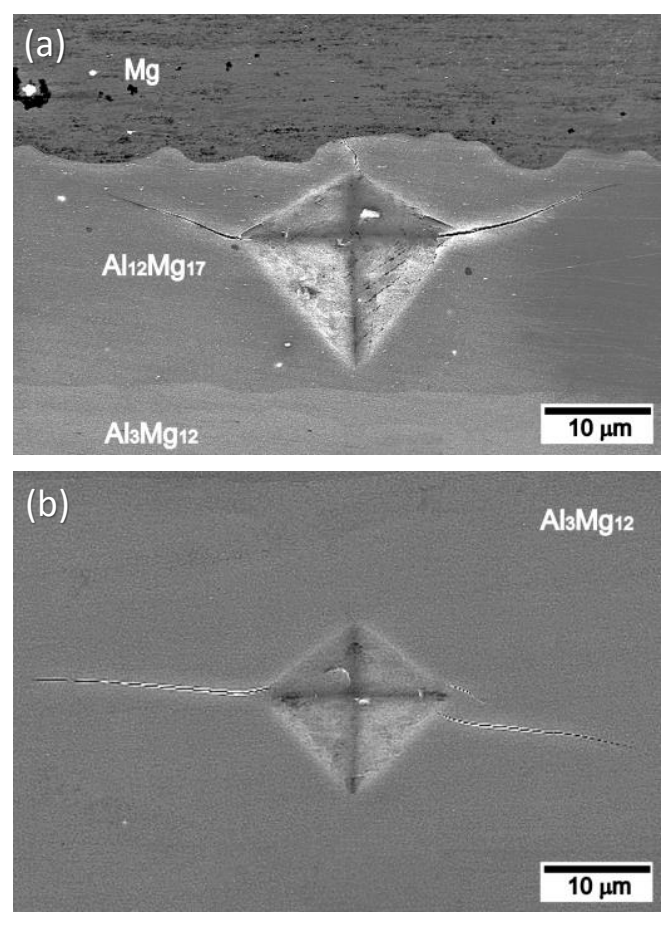

Fig. 13 SEM images of typical microhardness indents in; (a) the $\gamma-\mathrm{Al}_{12} \mathrm{Mg}_{17}$ and (b) $\beta-\mathrm{Al}_{3} \mathrm{Mg}_{2} \mathrm{IMC}$ layers formed at the interface of an $\mathrm{Al}-\mathrm{Mg}$ dissimilar joint, annealed at $400{ }^{\circ} \mathrm{C}$ for 3 hours, showing cracks used for toughness estimates emanating from their corners.

Indentation crack lengths were measured by SEM imaging of the microhardness test samples (Fig. 14). In Fig. 13 it can be seen that in both phases the cracks tended to propagate preferentially along the joint interface, while in the direction normal to the interface the cracks were either obviously affected by the thin geometry of the layer, in the case of $\gamma-\mathrm{Al}_{12} \mathrm{Mg}_{17}$, or for the $\beta-\mathrm{Al}_{3} \mathrm{Mg}_{2}$ phase did not develop at all. For this reason, fracture toughness was only calculated using crack lengths measured horizontally in the interface plane. By using Equation 5, the fracture toughness for $\gamma-\mathrm{Al}_{12} \mathrm{Mg}_{17}$ was estimated to be $0.105 \mathrm{MPam}^{1 / 2}$ and $0.062 \mathrm{MPam}^{1 / 2}$ for $\beta-\mathrm{Al}_{3} \mathrm{Mg}_{2}$. It should be noted that the thin nature of the $\gamma-\mathrm{Al}_{12} \mathrm{Mg}_{17}$ layer, relative to the indent size, clearly affected the results (Fig. 13a), while values for the much thicker $\beta$ phase are more reliable (Fig. 13b). Nevertheless, it is interesting to note that the toughness values measured are very low compared to other IMC aluminide phases, being almost an order of magnitude lower than for comparable values for Ti or Fe aluminides (see Table 5). These results therefore confirm that the development of a 
continuous interface reaction layer, of either $\gamma-\mathrm{Al}_{12} \mathrm{Mg}_{17}$ or $\beta-\mathrm{Al}_{3} \mathrm{Mg}_{2}$, is very harmful to the mechanical performance of dissimilar $\mathrm{Al}-\mathrm{Mg}$ welds.

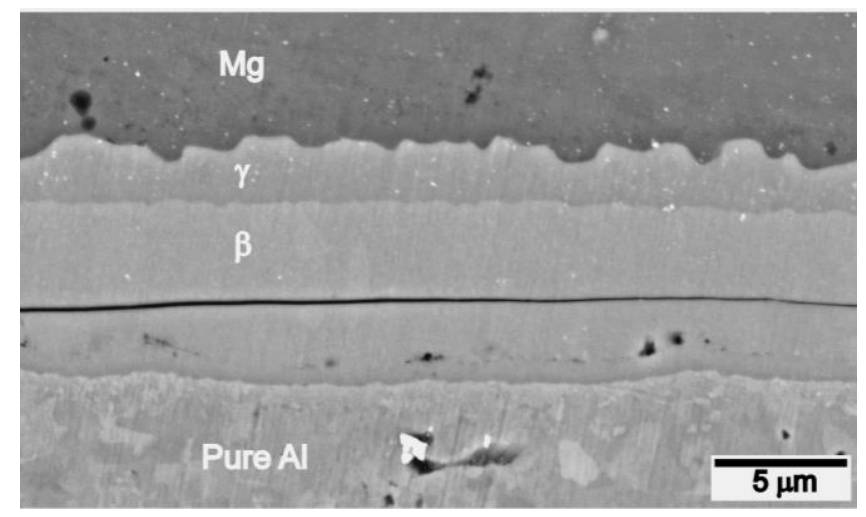

Fig. 14 Micrograph of a pure $\mathrm{Al}-\mathrm{AZ3} 1 \mathrm{Mg}$ diffusion couple $\left(360{ }^{\circ} \mathrm{C} / 10 \mathrm{~min}\right)$ subjected to a lap shear test, showing the crack propagating solely in the thicker $\beta-\mathrm{Al}_{3} \mathrm{Mg}_{2}$ phase.

\subsection{Residual Stress Analysis}

From Fig. 13 and 14 it is apparent that interfacial cracking typically propagates within the IMC layers in the interface plane (x), while in the normal direction $(\mathrm{z})$, cracking is largely prohibited. A similar asymmetric behavior has been observed in the $\gamma-\mathrm{Al}_{12} \mathrm{Mg}_{17}$ phase by Venkateswaran et al.[36], who reported that the toughness parallel to the interface was smaller than in the perpendicular direction (see Table 5).

Various factors can potentially lead to the anisotropic growth of a crack in an IMC reaction layer, including the influence of constraint, owing to its thin dimensions, the presence of a directional grain structure, or texture, and pre-existing residual stresses. Here, even in the $\beta$ phase, which was five times thicker than the indent size used in the sample tested, cracking was still found to develop preferentially in the plane of the interface, transverse to the columnar grain structure when no obvious crystallographic texture was detected (Section 3.3). To help explain this preferential crack growth behavior micro-residual stress measurements were performed on the $\gamma-\mathrm{Al}_{12} \mathrm{Mg}_{17}$ and $\beta-\mathrm{Al}_{3} \mathrm{Mg}_{2}$ phases using the ring-core FIB milling technique described in $\S 2.3$.

As shown in Fig. 15, where the principle strains measured by DIC are plotted against the depth to pillar diameter ratio $(\mathrm{h} / \mathrm{d})$, significant strain relaxation occurred in both the $\gamma-\mathrm{Al}_{12} \mathrm{Mg}_{17}$ and $\beta-\mathrm{Al}_{3} \mathrm{Mg}_{2}$ phases with increasing milling depth. In both IMC layers the strain component measured parallel to the interface plane (x-direction) had a positive value $(\mathrm{x})$, indicating that there was an expansion when the constraining surrounding material was removed, whereas in the normal (z) direction, a negative strain was detected. This relaxation behavior indicates the presence of 
substantial residual stresses within each IMC layer that are compressive, parallel to, and tensile, normal to, the interface plane. With increasing milling depth, the absolute values of both the $\mathrm{x}$ and $\mathrm{y}$ strain components increased until they reached maximum values, at a relative milling depth of 0.4 , at which point the surface in-plane residual strains can be assumed to have fully relaxed. For relative milling depths greater than 0.6 , the results became unreliable because re-deposition of sputtered material caused the reference pattern milled in the Pt coating to lose its definition (Fig. 2). The maximum values of the relaxation strains measured for the $\gamma-\mathrm{Al}_{12} \mathrm{Mg}_{17}$ phase were approximately $\varepsilon_{\mathrm{x}}=-0.1 \%$ and $\varepsilon_{\mathrm{z}}=0.05 \%$, but were significantly larger for the $\beta-\mathrm{Al}_{3} \mathrm{Mg}_{2}$ phase with, $\varepsilon_{\mathrm{x}}=-0.4 \%$ and $\varepsilon_{\mathrm{z}}=0.2 \%$.
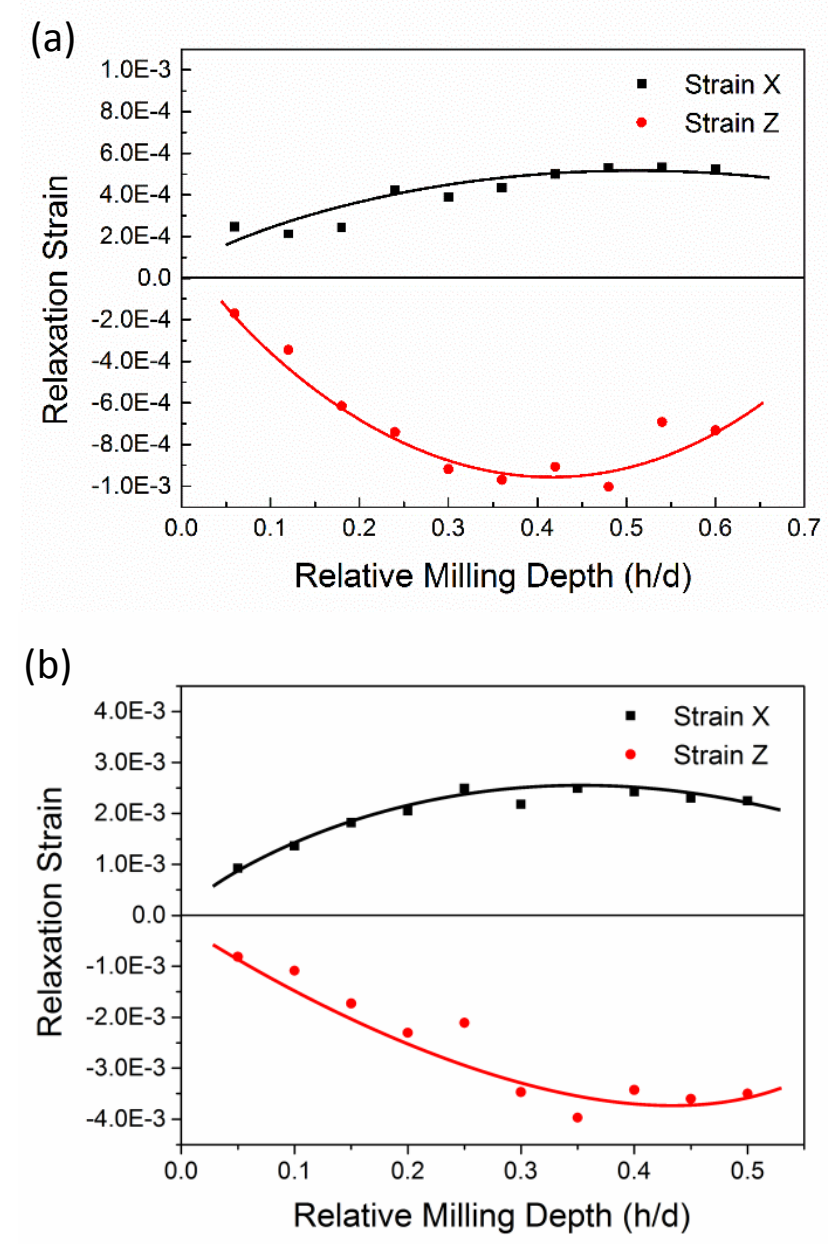

Fig. 15 Strain components measured parallel to $(\mathrm{x})$ and normal $(\mathrm{z})$ to the interface plane, during ring core milling (a) the $\gamma-\mathrm{Al}_{12} \mathrm{Mg}_{17}$ and (b) $\beta-\mathrm{Al}_{3} \mathrm{Mg}_{2}$ IMC layers, as a function of the relative milling depth $(\mathrm{h} / \mathrm{d})$.

As the welded area in the samples was large, relative to the thickness of the reaction IMC layer, in a bulk sample the stress state at the center of a spot weld within the IMC layer should be approximately axisymmetric, with the $\mathrm{x}$ - and $\mathrm{y}$-components in the interface plane being equivalent 
(i.e. $\sigma_{\mathrm{x}}=\sigma_{\mathrm{y}}$ ). However, when the samples were cross sectioned the out-of-plane stress $\sigma_{\mathrm{y}}$ will have been relaxed, resulting in a state of plane stress. As no texture was measured, by assuming isotropic elastic properties after sectioning the residual stresses can be estimated from:

$$
\begin{array}{ll}
\sigma_{\mathrm{x}}=-\frac{E}{\left(1-v^{2}\right)}\left(\varepsilon_{\mathrm{x}}^{*}+v \varepsilon_{\mathrm{y}}^{*}\right) & \text { Equation } 5 \\
\sigma_{\mathrm{z}}=-\frac{E}{\left(1-v^{2}\right)}\left(\varepsilon_{\mathrm{z}}^{*}+v \varepsilon_{\mathrm{x}}^{*}\right) & \text { Equation } 6
\end{array}
$$

Where $\varepsilon_{\mathrm{x}}^{*}$ and $\varepsilon_{\mathrm{z}}^{*}$ are the maximum strains measured from the fully relaxed surface of the pillar. Poisson ratio, $v$, is unknown but can be approximated to be 0.33 . Using $E$, the elastic modulus of each phase, from Table 5, the principle residual stresses calculated from the strain data in Fig. 16, were $\sigma_{\mathrm{x}}=-15.81 \mathrm{MPa}$ and $\sigma_{\mathrm{z}}=67.21 \mathrm{MPa}$ for the $\gamma-\mathrm{Al}_{12} \mathrm{Mg}_{17}$ phase, and $\sigma_{\mathrm{x}}=-90.70 \mathrm{MPa}$ and $\sigma_{\mathrm{z}}=266.75 \mathrm{MPa}$ for $\beta-\mathrm{Al}_{3} \mathrm{Mg}_{2}$ phase. It can therefore be noted that the residual stresses in the $\beta$ phase are substantially higher and particularly large in a tensile sense normal to the interface plane.

Residual stresses in the IMC phases will arise partly from any volume change, when they form and partly due to the effects of differential thermal expansion between the IMC layers and the weld members when the samples cool to room temperature. The average volume occupied per atom in the unit cells of both IMC phases is about $20 \AA^{3}$ [22], which is approximately $17 \%$ greater than for $\mathrm{Al}$ and $15 \%$ less than for $\mathrm{Mg}$; i.e. due to the volume change arising from IMC growth the stronger Al alloy would be expected to impose a compressive constraint parallel to the weld interface. However, the situation is further complicated by the fact that the two ( $\mathrm{Al}$ and $\mathrm{Mg}$ ) parent alloys will plastically relax at different rates with falling temperature, although they both have expansion coefficients that are likely to be far larger than those of the IMC phases (e.g. Al $\sim 23, \mathrm{Mg} \sim 25 \mu \mathrm{m}$ $\mathrm{m}^{-1} \mathrm{~K}^{-1}$ ). In the $\mathrm{x}-\mathrm{y}$ directions, parallel to the interface plane, it is thus apparent that on cooling differential contraction will generate a compressive stress in the IMC layer from the large contraction of the weld members, which is likely to be greater in the stronger Al alloy due to a lower level of relaxation. In the interface normal direction (z), a tensile stress might also be expected from the fact that the ultrasonic spot weld is holding the two dissimilar metals together only locally and differential contraction will occur on cooling of the bimetallic sheets, creating a bending moment, which will try to separate the sheets.

It should be noted that this is a preliminary analysis, and for a more accurate evaluation of the 
absolute values of the stress components in three dimensions, a full finite element (FE) simulation would be required of both the core relaxation and sample behavior. Nevertheless, the results suggest that residual stresses in both IMC layers will tend to hinder cracking normal to the interface and promote propagation in the interface plane. Consequently, the IMC layers exhibited a lower apparent in-situ fracture toughness in the plane of the weld interface. In addition, much larger residual stresses were detected in the $\beta-\mathrm{Al}_{3} \mathrm{Mg}_{2}$ phase, which could explain its inferior fracture behavior in indentation tests (Table 5). This assessment also agrees with the observation that interfacial cracks were found to only grow within the $\beta-\mathrm{Al}_{3} \mathrm{Mg}_{2}$ phase in lap shear tests, as illustrated in Fig. 13.

\subsection{Conclusions}

The formation of IMC phases at a joint interface in dissimilar metal welds plays a crucial role in limiting joint performance. In this research, a comprehensive investigation has been performed of the solid-state intermetallic reactions found at the interface in $\mathrm{Al}-\mathrm{Mg}$ dissimilar welds. The results have been compared to data reviewed from the literature, with close agreement in most cases; however, several important new findings have been made. Overall, the assessed data can be more confidently used to provide guidance in the future development of $\mathrm{Al}-\mathrm{Mg}$ dissimilar joining technologies, and confirms that preventing interfacial reaction in this system is a major challenge, because of the high growth rate of the IMC phases and their intrinsically poor mechanical properties.

Three intermetallic phases, namely the $\gamma-\mathrm{Al}_{12} \mathrm{Mg}_{17}, \varepsilon-\mathrm{Al}_{30} \mathrm{Mg}_{23}$ and $\beta-\mathrm{Al}_{3} \mathrm{Mg}_{2}$ phase, were confirmed to form during long-term static annealing by EBSD and TEM analysis. The $\varepsilon-\mathrm{Al}_{30} \mathrm{Mg}_{23}$ phase has, for the first time, been identified in an $\mathrm{Al}-\mathrm{Mg}$ diffusion couple, but its formation was found to lag greatly behind that of the other two IMCs and is thus not that relevant to welding. In contrast, within the temperature range of interest to solid-state welding, the $\beta-\mathrm{Al}_{3} \mathrm{Mg}_{2}$ phase appeared shortly after $\gamma-\mathrm{Al}_{12} \mathrm{Mg}_{17}$, had the highest growth rate, and rapidly developed to be the dominant reaction product. The subsequent growth of a dual $\mathrm{Al}_{12} \mathrm{Mg}_{17} / \mathrm{Al}_{3} \mathrm{Mg}_{2} \mathrm{IMC}$ interface layer occurred through the $\beta$ phase growing into the $\mathrm{Al}$ substrate and consuming the $\mathrm{Al}_{12} \mathrm{Mg}_{17}$ phase, while the $\gamma$ phase only grew into the $\mathrm{Mg}$ alloy substrate. Both phases were found to adopt a columnar grain morphology, but without any preferred crystallographic texture.

In the AA6111-AZ31 diffusion couples constituent particles originating from the Al alloy were observed to be left behind and agglomerate in a particle-rich sublayer at the $\beta-\mathrm{Al}_{3} \mathrm{Mg}_{2} / \mathrm{Al}$ interface, 
due to the loss of $\mathrm{Al}$ into the IMC layer. Using the constituent particles as diffusion markers, allowed estimates to be made of the intrinsic diffusion coefficients in the $\mathrm{Al}_{3} \mathrm{Mg}_{2}$ phase, the results of which confirmed that $\mathrm{Al}$ was the faster diffusion species at temperatures typical of solid-state welding.

Indentation methods were used to characterize the mechanical properties of the $\beta-\mathrm{Al}_{3} \mathrm{Mg}_{2}$, $\varepsilon-\mathrm{Al}_{30} \mathrm{Mg}_{23}$ and $\beta-\mathrm{Al}_{12} \mathrm{Mg}_{17}$ phases. Of the three IMCs, the $\beta$ was found to have the greatest hardness, while its modulus was inferior to that of $\gamma$. Both the $\beta$ and $\gamma$ phases exhibited a lower cracking resistance laterally than normal to the weld interface and were measured to have very low fracture toughness values. In addition, the toughness of $\beta-\mathrm{Al}_{3} \mathrm{Mg}_{2}$ phase in the interface plane $\left(0.062 \mathrm{MPam}^{1 / 2}\right)$ was measured to be much lower than that of $\gamma-\mathrm{Al}_{12} \mathrm{Mg}_{17}\left(0.105 \mathrm{MPam}^{1 / 2}\right)$. As a result, interfacial cracks were found to propagate preferentially laterally within the $\beta$ layer.

Substantial residual stresses were measured in the $\beta-\mathrm{Al}_{3} \mathrm{Mg}_{2}$ and $\gamma-\mathrm{Al}_{12} \mathrm{Mg}_{17}$ IMC layers by the FIB ring milling method. In both cases the stress component normal to the interface was found to be positive, which had the effect of promoting the extension of lateral cracks, while the horizontal components were compressive, which would hinder crack growth normal to the interface. These results correlated directly to the asymmetric fracture resistance found for the two IMCs. Moreover, a higher residual stresses was measured in the $\beta-\mathrm{Al}_{3} \mathrm{Mg}_{2}$ phase, compared to in $\gamma-\mathrm{Al}_{12} \mathrm{Mg}_{17}$. Taken together, these results thus explain why failure of welds during lap-shear tests was found to predominantly be caused by interfacial crack propagation in the $\beta$ phase.

\section{Acknowledgements}

This work was funded by the EPSRC throughLATEST2, Light Alloys towards Environmentally Sustainable Transport (EP/H020047/1). The authors acknowledge the China Scholarship Council (CSC, 2011612007) for financial support and would like Novelis UK and Magneisum Electron for the provision of materials.

\section{References}

[1] J. Hirsch, Materials Trans. 52 (2011) 818-824

[2] A. Panteli, J.D. Robson, I. Brough, P.B. Prangnell, Mater. Sci. Eng. A, 556A (2012) 31-42.

[3] A. Simar and M-N. Avettand-Fènoël: Sci. Technol. Weld Joining, 22 (2017) 389-403

[4] U.Suhuddin, V.Fischer, F.Kroeff, J.F.dosSantos: Mater. Sci. Eng. A, 590A (2014) 384-389. 
[5] H.M. Rao, J.B. Jordon B. Ghaffari, X. Sub, A.K. Khosrovaneh, M.E. Barkey, W. Yuan, M. Guo: Int. J. of Fatigue, 82 (2016) 737-747.

[6] Z. Liang, G. Qin, H. Ma, F. Yang and Z. Ao: Sci. Technol. Weld Joining, 22 (2017) 363-372.

[7] J. Murray, Bulletin of Alloy Phase Diagrams, 3 (1982) 60-74.

[8] E. Schurmann, H. Voss, Giessereiforschung, 33 (1981) 43-46.

[9] H.L. Su, M. Harmelin, P. Donnadieu, C. Baetzner, H.J. Seifert, H.L. Lukas, G. Effenberg, F. Aldinger, J. Alloys Compounds, 247 (1997) 57-65.

[10] E.T. Njiokep, M. Salamon, H. Mehrer, Defect Diffusion Forum, 194-199 (2001) 1581-1586.

[11] Y. Minamino, T. Yamane, T. Miyake, M. Koizumi, Y. Miyamoto, Mater. Sci. Technol. 2 (1986) 777-783.

[12] J. D. Robson, A. Panteli, P. B. Prangnell, Science technol Welding and Joining, 17 (2012) 447-453.

[13] Z.F. Li, J. Dong, X.Q. Zeng, C. Lua, W.J. Ding, Z.M. Ren, Alloys Compounds, 440 (2007) 132-136.

[14 P. Liu, Y. Li, H. Geng, J. Wang, Mater. Lets. 59 (2005) 2001-2005.

[15] P. Liu, Y. Li, H. Geng, J. Wang, Vacuum, 80 (2006) 395-399.

[16] J. Wang, Y. Li, P. Liu, H. Geng, J. Mater. Process. Technol. 205 (2008) 146-150.

[17] Y. Li, P. Liu, J. Wang, H. Ma, Vacuum, 82 (2008) 15-19.

[18] X. Li, W. Liang, X. Zhao, Y. Zhang, X. Fu, F. Liu, J. Alloys Compounds, 471 (2009) 408-411.

[19] P. Schobinger-Papamantellos, P. Fischer, Kurze Originalmitteilungen Kristallographie, 57 (1970) 128-129.

[20] D. Dietrich, D. Nickel, M. Krause, T. Lampke, M. Coleman, V. Randle, J. Mater Sci, 46 (2011) 357-364.

[21] L. Wang, Y. Wang, P. Prangnell, J. Robson, Metal. Mater Trans. A, 46A (2015) 4106-4114.

[22] S. Samson, Acta Cryst. 19 (1965) 401-413.

[23] J. Wolnya, B. Kozakowski, M. Duda and J. Kusz, Phil Mag. Lets, 88 (2008) 501-507.

[24] P. Jeglič, M. Komelj, M. Klanjšek, U. Tkalec, S. Vrtnik, M. Feuerbacher, and J. Dolinšek, Physical Review B, 75B (2007) 014202, 1-15.

[25] M. Pekguleryuz, Alloying behavior of magnesium and alloy design. In: M. O. Pekguleryuz, K.

U. Kainer \& A. A. Kaya, eds. Fundamentals of magnesium alloy metallurgy, (2013) Woodhead Publishing Ltd, pp. 161-163.

[26] A. Panteli, Y.-C. Chen, D. Strong, X. Zhang, P. Prangnell, J Minerals, Metals Mater. Soc. JOM, 64 (2012) 414-420.

[27] G. Anstis, P. Chantikul, B. Lawn, D. Marshall, J. American Ceramic Soc. 64 (1981) 533-538. 
[28] M. Sebastian, C. Eberl, E. Bemporad, G. Pharr, Mater. Sci. Eng. A, 528A (2011) 7901-7908.

[29] X. Chen, J. Langlais, Mater. Sci. Forum, 331-337 (2000) 215-222.

[30] K. Wu, J.E. Morral and Y. Wang, Acta Mater. 49 (2001) 3401-3408

[31] L. Boltzmann, Annalen der Physik, 53 (1894) 959-964.

[32] S. Brennan, K. Bermudez, N. Kulkarni, Y. Sohn, Metal. Mater. Trans A, 43A (2012) 4043-4052.

[33] U.F.H. Suhuddin, V. Fischer and J.F. dos Santos: Scripta Mater. 68 (2013) 87-90.

[34] A. Gerlich, P. Su, T. North, Sci. Technol. Welding Joining, 10 (2005) 647-652.

[35] S. Samson, Acta Crystallographica, 24 (1968) 1004-1013.

[36] P. Venkateswaran, Z. Xu, X. Li, A. Reynolds, J Mater Sci. 44 (2009) 4140-4147.

[37] A. Zolriasateiin, A. Shokuhfar, Mater. Design, 75 (2015) 17-23.

[38] T. Yener, S. Guler, S. Siddique, F. Walther, S. Zeytin, Acta Physica Polonica A, 129A (2016) 604-606.

[39] P. Matysik, S. Jóźwiak and T. Czujko, Materials, 8(3) (2015) 914-931.

[40] M.J. Rathod, M. Kutsuna, Welding J, Jan. (2004) 16-26.

[41] M. Zhang, H. Huang, K. Spencer, Y. Shi, Surface Coatings Technol. 204 (2010) 2118-2122.

[42] J. Pang, X. Cui, A. Li, G. Fan, L. Geng, Z. Zheng, Q. Wang, Mater. Sci. Eng. A, 579A (2013) $57-63$.

[43] V. Maier, H.W. Hoppel, M. Goken, 15th Int. Conf. on the Strength of Materials (ICSMA-15) J Phys. (2010) Conf. Ser. 240, 012108; (http://iopscience.iop.org/1742-6596/240/1/012108)

[44] W. Wang, T. Yamaguchi, K. Nishio, Mater. Trans. 55 (2014) 1698-1706.

[45] A. Radziszewska, S. Kac, M. Feuerbacher, Acta Physica Polonica A, 117A (2010) 799-802.

[46] M. Feuerbacher, C. Thomas, J. Makongo, S. Hoffmann, Z. Kristallographie, 222 (2009) 259-288.

[47] H. Zhang, S. Shang, Y. Wang, A. Saengdeejing, L. Chen, Z. Liu, Acta Materialia, 58 (2010) 4012-4018.

[48] D. Zhou, J. Liu, S. Xu, P. Peng, Physica B: Condensed Matter, 405B (2010) 2863-2868.

[49] X. Yin, N. Travitzky, P. Greil, J. American Ceramic Soc. 90 (2007) 2128-2134.

[50] G.R. Anstis, P. Chantikul, B.R. Lawn, D.B. Marshall, J. American Ceramic Soc. 63 (1980) 533-538. 


\section{Figure Captions}

Fig. 1 The revised middle section of Al-Mg phase diagram proposed by Su et al. [9].

Fig. 2 Example of the cumulative ring-core milling procedure taken at an intermediate milling step.

Fig. 3 The interfacial microstructure of the USW $\mathrm{Al}(\mathrm{AA} 6111)-\mathrm{Mg}(\mathrm{AZ31})$ samples prior to heat treatment; (a) EBSD Euler angle map, (b) EBSD phase map and (c) SEM image of the interface, showing a single thin reaction layer.

Fig. 4 Interfacial morphology of an $\mathrm{Al}-\mathrm{Mg}$ sample after a short heat treatment of 5 minutes at 400 ${ }^{\circ} \mathrm{C}$ : (a) BSE micrograph of the interfacial area; (b) enlarged BSE micrograph from the dashed box in (a); (c) and (d) Euler angle and phase maps, respectively, obtained by EBSD analysis.

Fig. 5 The interfacial morphology of an $\mathrm{Al}-\mathrm{Mg}$ sample after long-term heat treatment at $400{ }^{\circ} \mathrm{C}$ for $24 \mathrm{~h}$ : (a) BSE micrograph of the interfacial area, (b) EDX composition analysis along the red line in (a), (c) and (d) an Euler angle and phase maps, respectively, obtained by EBSD mapping the white box in (a).

Fig. 6 SEM micrograph showing the edge of the reaction area in the couple annealed at $360{ }^{\circ} \mathrm{C}$ for $24 \mathrm{hrs}$.

Fig. 7100,110 and 111 pole figures measured by EBSD from the (a) $\gamma-\mathrm{Al}_{12} \mathrm{Mg}_{17}$ and (b) $\beta-\mathrm{Al}_{3} \mathrm{Mg}_{2}$ IMC phases in an AA6111 - AZ31 sample annealed at $400{ }^{\circ} \mathrm{C}$ for $24 \mathrm{hrs}$.

Fig. 9 BSE image of the particle-rich $\beta_{\text {II }}$ sublayer after annealing at $400{ }^{\circ} \mathrm{C}$ for $72 \mathrm{hrs}$.

Fig 10. Interfacial microstructures of (a) the AA6111 - AZ31 and (b) the pure Al - AZ31 interdiffusion samples, after heat-treatment for 3 hours at $360{ }^{\circ} \mathrm{C}$.

Fig. 11 The $\varepsilon$ phase in $\mathrm{Al}-\mathrm{Mg}$ diffusion couples at the interface between the $\beta$ and $\gamma$ IMC layers after longer-term heat treatment; (a) BSE micrograph after 24 hours at $360{ }^{\circ} \mathrm{C}$; (b) and (c) EBSD band contrast and phase maps obtained by EBSD analysis of a sample after 72 hours at $400{ }^{\circ} \mathrm{C}$ ( $\varepsilon$ is indicated by arrows).

Fig. 12 TEM characterization of the $\varepsilon$ phase in an $\mathrm{Al}-\mathrm{Mg}$ couple annealed at $400{ }^{\circ} \mathrm{C}$ for 72 hours; (a) an EDX line scan profile across the interface between the $\beta$ and $\gamma$ phase; (b) a diffraction pattern taken from the $\gamma$ phase and (c) - (e), diffraction patterns showing different zone axes indexed as 
$\varepsilon-\mathrm{Al}_{30} \mathrm{Mg}_{23}$.

Fig. 13 SEM images of typical microhardness indents in; (a) the $\gamma-\mathrm{Al}_{12} \mathrm{Mg}_{17}$ and (b) $\beta-\mathrm{Al}_{3} \mathrm{Mg}_{2} \mathrm{IMC}$ layers formed at the interface of an $\mathrm{Al}-\mathrm{Mg}$ dissimilar joint, annealed at $400{ }^{\circ} \mathrm{C}$ for 3 hours, showing cracks used for toughness estimates emanating from their corners.

Fig. 14 Micrograph of a pure $\mathrm{Al}-\mathrm{AZ31} \mathrm{Mg}$ diffusion couple $\left(360^{\circ} \mathrm{C} / 10 \mathrm{~min}\right)$ subjected to a lap shear test, showing the crack propagating solely in the thicker $\beta-\mathrm{Al}_{3} \mathrm{Mg}_{2}$ phase.

Fig. 15 Strain components measured parallel to $(\mathrm{x})$ and normal $(\mathrm{z})$ to the interface plane, during ring core milling (a) the $\gamma-\mathrm{Al}_{12} \mathrm{Mg}_{17}$ and (b) $\beta-\mathrm{Al}_{3} \mathrm{Mg}_{2}$ IMC layers, as a function of the relative milling depth $(\mathrm{h} / \mathrm{d})$.

Table 1 Nominal compositions of the AA6111 and AZ31 alloys investigated (wt. \%).

Table 2 Comparison of kinetic rate constants for one-dimensional growth of the main Al-Mg IMC phases measured in the current study with data compiled from the literature.

Table 3 Typical compositions measured by EDX (in at\%) from the second phase particles found in the $\beta_{\mathrm{II}}$ sublayer after annealing at $400{ }^{\circ} \mathrm{C}$ for $72 \mathrm{hrs}$ and the matrix at the positions $(\mathrm{A}-\mathrm{C})$ marked in Fig. 9.

Table 4 Intrinsic diffusion coefficients for $\mathrm{Al}$ and $\mathrm{Mg}$ in the $\beta$ phase obtained from the current study compared to published literature.

Table 5 The mechanical properties of the Al-Mg IMC phases measured in this work (bold) compared to published values for Al-Mg, as well as to other common aluminide phases compiled from the literature. 
Table 1

\begin{tabular}{ccccccccc}
\hline & $\mathrm{Al}$ & $\mathrm{Si}$ & $\mathrm{Zn}$ & $\mathrm{Fe}$ & $\mathrm{Cu}$ & $\mathrm{Mn}$ & $\mathrm{Mg}$ \\
\hline AA6111 & Balance & $0.6-1.1$ & $<0.15$ & & $<0.4$ & $0.5-0.9$ & $0.1-0.45$ & $0.5-1$ \\
$\mathrm{AZ31}$ & $2.5-3.5$ & $<0.1$ & $0.7-1.3$ & - & - & $0.2-0.6$ & Balance \\
\hline
\end{tabular}

Table 2

\begin{tabular}{cccc}
\hline Phase & $k_{0}\left(\mathrm{~m}^{2} / \mathrm{s}\right)$ & $Q(\mathrm{~kJ} / \mathrm{mol})$ & Reference \\
\hline & $8.01 \times 10^{-8}$ & 72 & Current Study \\
$\beta$ & $3.5 \times 10^{-8}$ & 69 & {$[10]$} \\
& $5.3 \times 10^{-8}$ & 67 & {$[11$} \\
& $2.2 \times 10^{-8}$ & 57 & {$[13]$} \\
\hline & 0.32 & 168 & Current Study \\
$\gamma$ & 0.1 & 165 & {$[10]$} \\
& $3.4 \times 10^{-2}$ & 142 & {$[11]$} \\
\hline Entire IMC layer & 0.4 & 106 & {$[2]$} \\
\hline
\end{tabular}

Table 3

\begin{tabular}{cccccccccc}
\hline & $\mathrm{Al}$ & $\mathrm{Mg}$ & $\mathrm{Si}$ & $\mathrm{Fe}$ & $\mathrm{Cu}$ & $\mathrm{Mn}$ & $\mathrm{Ti}$ & $\mathrm{Zn}$ & $\mathrm{C}$ \\
\hline $\mathrm{A}$ & 78.4 & 2.6 & 1.1 & 15.3 & - & 2.5 & - & 0.1 & - \\
$\mathrm{B}$ & 58.5 & 35.9 & - & 0.1 & 0.9 & 0.2 & 0.1 & 0.1 & 4.2 \\
$\mathrm{C}$ & 16.7 & 54.9 & 23.7 & 0.1 & 0.1 & 0.2 & - & - & 4.3 \\
\hline
\end{tabular}

Table 4

Intrinsic Diffusion Coefficients

\begin{tabular}{ccc}
$D_{\mathrm{Al}}$ & $D_{\mathrm{Mg}}$ & Ref. \\
\cline { 1 - 3 }$\left(\mathrm{m}^{2} / \mathrm{s}\right)$ & $\left(\mathrm{m}^{2} / \mathrm{s}\right)$ & {$[32]$} \\
\hline $8.8 \times 10^{-14}\left(350^{\circ} \mathrm{C}\right)$ & $3.9 \times 10^{-15}\left(350^{\circ} \mathrm{C}\right)$ & Current study \\
$9.10 \times 10^{-14}\left(360^{\circ} \mathrm{C}\right)$ & $3.43 \times 10^{-15}\left(360^{\circ} \mathrm{C}\right)$ & {$[32]$} \\
$2.9 \times 10^{-13}\left(400^{\circ} \mathrm{C}\right)$ & $1.9 \times 10^{-14}\left(400^{\circ} \mathrm{C}\right)$ & \\
\hline
\end{tabular}


Table 5

\begin{tabular}{|c|c|c|c|c|c|}
\hline & & Al-Mg IMCs & & Tis & $\mathrm{FeAl}$ \\
\hline & $\beta-\mathrm{Al}_{3} \mathrm{Mg}_{2}$ & $\gamma-\mathrm{Al}_{12} \mathrm{Mg}_{17}$ & $\varepsilon-\mathrm{Al}_{30} \mathrm{Mg}_{23}$ & $11 \mathrm{AI}$ & ГЕАЗ \\
\hline \multirow{3}{*}{$\begin{array}{l}\text { Micro-Hardness } \\
\qquad\left(\mathrm{H}_{\mathrm{V}}\right)^{a}\end{array}$} & \multirow{3}{*}{$\begin{array}{c}\mathbf{2 8 9 . 4} \pm \mathbf{3 . 6} \\
370[20]\end{array}$} & $268.3 \pm 3.6$ & \multirow{3}{*}{-} & \multirow{3}{*}{$600[38]$} & \multirow{3}{*}{$\begin{array}{l}691[39] \\
892[40]\end{array}$} \\
\hline & & $265[36]$ & & & \\
\hline & & 253 [37] & & & \\
\hline \multirow{3}{*}{$\begin{array}{c}\text { Nano-Hardness } \\
(\mathrm{GPa})^{b}\end{array}$} & \multirow{3}{*}{$\begin{array}{c}\mathbf{4 . 0 9} \pm \mathbf{0 . 1 0} \\
4.35[41]\end{array}$} & $3.82 \pm 0.18$ & \multirow{3}{*}{$3.39 \pm 0.03$} & & \multirow{3}{*}{$10.5[44]$} \\
\hline & & $5.18[36]$ & & $\begin{array}{c}9.2[42] \\
0[43]\end{array}$ & \\
\hline & & $4.4[41]$ & & & \\
\hline \multirow{5}{*}{$\mathrm{E}(\mathrm{GPa})$} & $63.49 \pm 1.27$ & $71.95 \pm 4.54$ & \multirow{5}{*}{$58.75 \pm 0.40$} & \multirow{5}{*}{$\begin{array}{l}141[38] \\
220[42]\end{array}$} & \multirow{5}{*}{284 [39] } \\
\hline & $60[20]$ & $70[20]$ & & & \\
\hline & $53.8[45]$ & $71[36]$ & & & \\
\hline & $66.8[41]$ & $78[47]^{c}$ & & & \\
\hline & $49.8[46]^{c}$ & $79.6[48]^{c}$ & & & \\
\hline \multirow{3}{*}{$\mathrm{K}_{\mathrm{IC}}\left(\mathrm{MPam}^{1 / 2}\right)$} & \multirow{3}{*}{$0.062^{d}$} & $0.105^{d}$ & & \multirow{3}{*}{$2[49]$} & \multirow{3}{*}{0.967 [39] } \\
\hline & & $0.27-0.37[36]^{d}$ & - & & \\
\hline & & $0.38-0.53[36]^{e}$ & & & \\
\hline
\end{tabular}

${ }^{a}$ Measured by microhardness tests; ${ }^{b}$ measured by nanoindentation tests; ${ }^{c}$ from theoretical calculations; ${ }^{d}$ calculated using crack lengths parallel to the interface only; ${ }^{e}$ Calculated using crack lengths parallel and normal to the interface plane. 